\title{
The stem cell biology of the protist pathogen Entamoeba invadens in the context of eukaryotic stem cell evolution
}

\author{
Vladimir F. Niculescu \\ Correspondence: vladimir.niculescu@yahoo.com

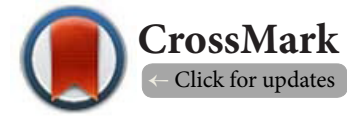

Kirschenweg 1, 86420 Diedorf, Germany.

\begin{abstract}
Entamoeba invadens is not the secondarily reduced and simplified eukaryote unrelated to a cenancestor as thought by some protist researchers. On the contrary, E. invadens is a single-celled eukaryote with a complex life cycle comprised of stem cells and stem cell lines. It contains hypoxic and oxygenic life cycle stages revealing to us details about the living conditions of LECA at the time of Unikonts' and Excavata's divergence. At the end of the super group evolution are protists such as Entamoeba and Giardia and metazoans such as Hydra and humans. Stem cells in Entamoeba and humans are controlled by the same basal mechanisms. At the time of super group divergence LECA had an anaerobic metabolism similar to that of Entamoeba; it contains non-aerobic mitochondria, different metabolic pathways using oxygen or not, anti-oxidative defense mechanisms against oxygen and a life cycle organized with a stem cell lineage. LECA evolved in the Proterozoic age from a unique vegetative cell type living in strict hypoxic environments (temporarily protected by a cyst wall) to a more and more complex cell system capable of living and proliferating in a wide range of hypoxic and moderate oxygenic niches. In conditions of alternating oxygen-, nitrogen- and nutrient- cycles LECA developed the characteristics of a true stem cell protolineage and transferred them to protist divergents and early animals. Without this ancestral heritage, protists such as E. invadens would not be able to become pathogens. They would live in a commensal relationship with their host. The metabolic anaerobe LECA is the common cenancestor of all eukaryotic stem cell lineages.
\end{abstract}

Keywords: Entamoeba invadens, ancient stem cells (AnSC), stem cell lineage, induced terminal differentiation, autonomous terminal differentiation, LECA, life cycle, stem cell protolineage

\section{Introduction}

In 1974 we discovered ancient stem cells (AnSC) in long-term cultures of $E$. invadens grown in hypoxic sediments with metabolically repressed OCB [1]. We observed two distinct stem cell lines, which were then called "cell classes" [2]. One of them is an oxygenic, self-renewing stem cell line (SRL) that is observed in the early growth phase (t0-t28) leading to an autonomous terminal differentiation for cyclic encystment (CE). The second is a more hypoxic SRL proliferating until the end of growth phase (t0-t96) in changing hypoxic conditions, giving rise to mitotic arrested quiescent cells ( $\mathrm{G} 0$ cells) capable of reentering the cell cycle. These findings were described in detail [3] and provide evidence that the mechanisms for cell differentiation and stemness were inherited from LECA. Basal mechanisms of cell differentiation and stemness were conserved not only in Entamoeba but also in protists such as Giardia and Colpoda $[4,5]$. The origin of stemness and AnSC lineages in single-celled eukaryotes was separately reported [6].

In 1974 the modern stem cell biology was still in its beginnings. Many biologists could barely remember the work of Ernst Häckel $[7,8]$ or not knew nothing at all. Although the term "Stammzelle" (German for stem cell) was introduced by Ernst Häckel for unicellular ancestors-that took over basal mechanisms of cell differentiation in modern eukaryotes-stem cells remained for long time a foreign concept in protist cell biology. Yet in 2012 peer-reviewers in Eukaryotic Microbiology argued that the stem cell terminolgy "dealing with metazoans, does not adress the various known stages in amoeba" and that parasitic amoebae represent a "secondarily reduced and simplified eukaryote" and "not something related to a cenancestor". Both statements have proven to be wrong and historically obsolete. They show deficits in understanding of the evolutionary cell biology of pathogen protists.

It is not to be overlooked that the term stem cell were used in 
Vladimir F. Niculescu, Stem Cell Biology and Research 2015,

the late $19^{\text {th }}$ century in the context of fundamental questions in embryology related to the germ plasm and the origin of the blood system [9]. In the early $20^{\text {th }}$ century-until 1974-there are a large number of stem cell publications focused only on human stem cells from haematopoietic tumors [10]. Becker, McCulloch and Till were the first researchers working with normal haematopoietic stem cells [11]. They described 1963 in mouse haematopoietic tissue a "class of cells" which can proliferate to macroscopic colonies. These colonies contain dividing cells capable of differentiation along three lines namely the erytrocytic, granulocytic and megakaryocytic series. HSC were established as the prototypical stem cells capable of nearly infinitely self-renewal and differentiation [9]. This current definition permits one to identify a variety of stem cells in other tissues and organisms, thus also the AnSC cells of E. invadens. After 1974 stem cells were discovered in human umbilical cord blood. A first stem cell line was obtained from mice in 1981, followed by stem cell lines from hamster (1988) and primates (1995) [12].

Phylogenetically speaking, the closest relatives to the protist AnSC stem cells of Entamoeba and Giardia are the stem cells of basal metazoans, such as, sponges and hydra, namely adult archeocytes and choanocytes. Although sponge cell lines could not be maintained in culture it is generally agreed that the archeocytes are likely to be the pluripotent stem cells in sponges [13]. After dissociation of the sponge body, the archaeocyte fraction aggregates and forms functional juvenile organisms [14]. Similar to stem cells from Entamoeba [3], differentiating archaeocytes from the fresh water sponges Ephydatia fluviatlis are large amoeboid cells with a highly proliferative and phagocytic activity [15], while choanocytes give rise only to gametes or convert back to archaeocytes [13]. Both AnSC from Entamoeba and basal metazoan as E. fluviatilis meet the current criteria of stem cells.

In the present paper I supplement the knowledge of Entamoeba's stem cell biology with unpublished data from my research work at the Department of Biology III and the Zoological Institute of the University of Tübingen, Germany. The protist life cycle is reinterpreted. These findings open new perspectives into the evolutionary stem cell history. Protist stem cell biology contradicts the conventional wisdom on stem cell development that considers eukaryotic stem cells to have originated from (Ur-) metazoa.

\section{Material and methods}

The $\mathrm{Aa}(\mathrm{SM})$ culture method developed during 1970-1974 was described in previous papers $[1,3]$. We cultured Entamoeba invadens in bottom sediments with oxygen consuming bacteria (OCB) metabolically repressed by antibiotics. As oxygen consuming associates we used Citrobacter [16] and later Aerobacter aerogenes [1,3]. Primary cell cultures were started with fresh ITD cysts induced for encystment in strong hypoxic OCB sediments covered by a hypoosmotic nutrientfree AaEM encystment medium. Subcultures were started from primary or secondary cultures.

\section{Organisms and conditioning}

The TR2/1 strain of E. invadens (Madagascar) was isolated in the 1960s by Douglas Cameron Barker from the Department of Zoology, University of Edinburgh, Scotland. For standard cultures the TR2/1 strain was grown in $10 \mathrm{ml}$ centrifuge U-tubes (glass) with $5 \mathrm{ml}$ of culture medium and the standard bacterial dose of $5 \mathrm{mg}$ of $\mathrm{A}$. aerogenes strain $\mathrm{AH} 8$ that was inhibited by bacteriostatic doses of streptomycin and erythromycin. The standard amoebic inoculum was approximately $1.0 \times 10^{6}$ amoebic cells per culture tube. After addition of amoebae, the tubes were centrifuged at $1000 \mathrm{rpm}$ to gently form a solid breeding culture sediment and kept in an incubator at $28^{\circ} \mathrm{C}$. The metabolic repressed OCB sediment consumes dissolved oxygen (DO) from the vicinity of amoebae providing an oxygen gradient in the culture tube. Parallel cultures were started with 5,10 and $15 \mathrm{mg}$ bacterial doses and $2.5 \times 10^{5}$ to $2.5 \times 10^{6}$ amoebic inoculi per culture. The culture medium must remain clear and not turbid. Superinfected turbid cultures were discarded.

\section{Stirring and re-centrifugation (SARC)}

Cell counting requires dispersion and homogenization of bottom sediments in culture medium. Dispersion is problematical, as stirring and homogenization change culture hypoxia. For establishing growth kinetics, parallel cultures were assessed and each culture tube was measured only once (e.g., t24, t48, t72, t96, t120). To understand the effects of homogenization and oxygenation on the amoebic population some of the samples were re-centrifuged at $1.000 \mathrm{rpm}$ and later underwent a second evaluation.

\section{Oxygen contents, $\mathrm{pO} 2$ and hypoxic range}

At the time the $\mathrm{Aa}(\mathrm{Sm})$ culture technique was established, there was no means to measure the oxygen content in the bottom sediment. Hypoxic effects were investigated by doubling and tripling the standard $\mathrm{OCB}$ dose and varying the quantity of amoebic inoculi.

\section{Hypoxic induced mass encystment}

Culture sediments containing self renewing stem cells of the QD24 ${ }^{\mathrm{LT}}$ line (D1 cells) and mitotic arrested quiescent QD cells (D2 cells) [3] were induced for encystment in conditions of nutrient depletion and strong hypoxia. Culture medium supernatant was gently removed by aspiration and substituted with $5 \mathrm{ml}$ phosphate buffer $\mathrm{pH} 5.5$ at $50 \mathrm{mOsm} / \mathrm{L}$ free of antibiotics (AaEM encystment medium). 10-15 mg A. aerogenes from a logarithmic $20 \mathrm{~h}$ bacterial culture was added and centrifuged, to form a adequate strong hypoxic OCB sediment capable of mass encystment.

\section{Results}

E. invadens develops in OCB sediments a sequence of primary, 
secondary and tertiary stem cells (P, S, T cells). It is a PST lineage containing three self-renewing stem cell lines namely the primary $(p-S R L)$, the secondary $(s-S R L)$ and the tertiary (t-SRL) line. The PST lineage is controlled by environmental factors such as oxygen consumption by bacteria and bacterial depletion by amoebae (phagocytosis). The assumptions made are that dissolved oxygen tension (pO2) in $26^{\circ} \mathrm{C}$ cultures is at about $8.1 \%$ (temperature-dependent DO concentration for solutions) and OCB associates progressively consume oxygen thus increasing hypoxia in the vicinity of amoebae. Based on these assumptions, we investigated (i) the regulatory effects of low, middle and high hypoxic OCB sediments by starting the cultures with initial bacterial doses of 5, 10 and $15 \mathrm{mg}$, as well as (ii) the effects of oxidative stress caused in cultures by stirring and recentrifugation (SARC). Culture homogenisation brings oxygen-derived stress for the metabolic anaerobe $E$. invadens, inducing changed expression of genes and proteins [17]. We present results describing the interrelation between the stem cell lineage of E. invadens and metabolic niches, mimicked in vitro by OCB sediments.

Sediment hypoxia increased when subcultures start with a new bacterial dose and decreased by phagocytic depletion, bacterial aging or further passages. Culture hypoxia evolved following a Gaussian curve with an ascendant and a descendent phase. The amplitude of the curve depends on the metabolic quality of the added bacteria, if they are freshly produced or preserved in refrigerator. Lineage development depends ultimately on the height and width of the hypoxic curve.

\section{Primary culture}

\section{The initiation phase in the primary culture}

The life cycle of $E$. invadens starts from the totipotent precursor that is the tetranucleated innercyst cell (8C polyploid cell). It hatched during the early initiation phase of the primary culture. We start the primary culture from cysts induced by the AaEM encystment medium for hypoxic encystment (ITD cysts). In contrast to the initiation phase observed in LT cultures [3], primary cultures have a prolonged initiation phase due to metacystic events following ex-cystment. During the metacystic phase the four polyploid nuclei of the recently hatched metacyst ( $M$ cell) divide again and again by a series of nuclear divisions (late karyokinesis) producing an octonucleated M8 cell (Table 7) $[124,125]$. Finally, the M8 metacyst give rise to eight uninucleated amoebulae (A cells) by cytokinesis. In OCB sediments A cells decide for stemness and asymmetric cell fate. This decision occurs probably at a switching point for asymmetric proliferation (I) that decides for arithmetic proliferation by asymmetric cell division. The initiation phase of the primary culture ends at the moment as A cells divide in two non-identical daughter cells (primary D1 and D2 cells).

\section{Primary $P$ cells and the asymmetric cell fate}

Primary D1 cells (SRP cells) are self-renewing cycling stem cells

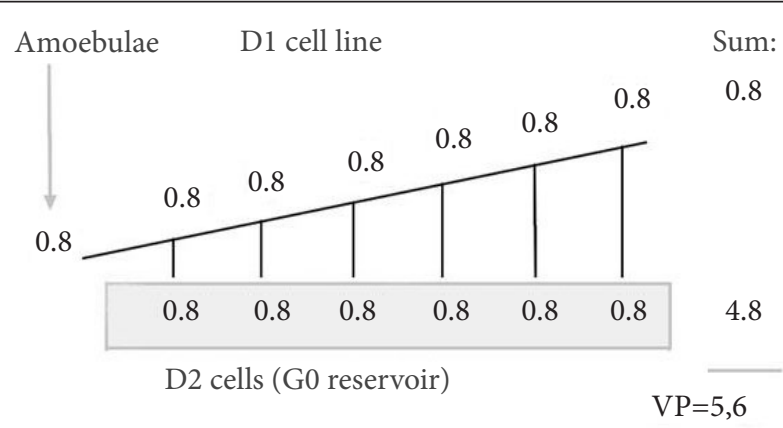

Figure 1. The primary self renewing p-SRL line and the primary stem cell reservoir.

Between $\mathrm{t}=0$ and $\mathrm{t}=96$ the primary population from the Table 2 complets six cycles of asymmetric cell division. In this way, a constant self-renewing stem cell fraction ( $\mathrm{p}-\mathrm{SRL}$ ) with $0.8 \times 10^{6} \mathrm{D} 1$ cells (SRP cells) develops a quiescent stem cell reservoir of about $4.8 \times 10^{6} \mathrm{MAP}$ cells (D2 $2^{1-6}$ cells).

while primary D2 cells exit the cell cycle as mitotic arrested stem cells (quiescent MAP cells) (Table 1). Mitotic arrested stem cells assume a G1/G0 phenotype retaining phagocytic activity. They play a role as reserve stem cells (RSC) re-entering cell cycle when passaged in subcultures. Cycling SRPs form the self-renewing stem cell line $\mathrm{p}$-SRL. Until the end of the culture the primary $\mathrm{p}$-SRL stem cell line divides asymmetrically and remains the same size, namely eight times the number of the cysts used to inoculate the culture. Neither SRP nor MAP cells encyst during growth. The primary stem cell population remains homogenous (only $P$ cells) and cyst free.

\section{Self renewing primary cells (SRP, D1 cells)}

As long as the culture sediments described in Table 2 remained undisturbed and samples for counting were taken only in the pre-stationary or stationary phase (t96-t120), decreasing sediment hypoxia by bacterial depletion does not affect $\mathrm{p}$-SRL proliferation. The primary line $\mathrm{p}-\mathrm{SRL}$ in the Figure 1 undergoes in the first $96 \mathrm{~h}$ (t0-t96) six asymmetric cell divisions (five complete and an incomplete cell cycle). Purely mathematically, the AGT value of the $p-S R L$ would be of about 15-16 $\mathrm{h}$ considering an initiation phase of about $10 \mathrm{~h}$.

The primary $\mathrm{p}-\mathrm{SRL}$ is a non-continuous stem cell line. Its life span ends by bacterial penury at the end of the primary culture or by cell passages into subcultures, where P cells convert into one of the subsidiary stem cell lines, s-SRL or t-SRL. $p$-SRL is a multipotent stem cell line, with bilateral conversion capacity. They generate secondary (S) or tertiary (T) stem cells by $\mathrm{P} / \mathrm{S}$ or P/T conversion (Table 1 ).

\section{Mitotic arrested MAP cells (RSC, D2 cells)}

After each division the MAP progeny remain mitotic quiescent (G0 state) and increased the primary stem cell reservoir. The stem cell reservoir counts the fraction of reserve stem cells RSC [19]. In fact, hypoxic stem cell cultures grew only by the MAP fraction, which increases with each new asymmetric 
Vladimir F. Niculescu, Stem Cell Biology and Research 2015,

http://www.hoajonline.com/journals/pdf/2054-717X-2-2.pdf

doi: $10.7243 / 2054-717 \mathrm{X}-2-2$

Table 1. The ancient stem cell system of Entamoeba invadens.

\begin{tabular}{lllllll}
\hline Cell type & Cell line & $\begin{array}{l}\text { Conversion } \\
\text { capacity }\end{array}$ & $\begin{array}{l}\text { Self renewing cells } \\
\text { (cycling D1 cells) }\end{array}$ & $\begin{array}{l}\text { Cell cycle duration } \\
\text { (in hr.) }\end{array}$ & $\begin{array}{l}\text { Arrested cells } \\
\text { (quiescent D2) }\end{array}$ & $\begin{array}{l}\text { Terminal } \\
\text { differentiation }\end{array}$ \\
\hline $\mathrm{P}$ & $\mathrm{p}-\mathrm{SRL}$ & $\mathrm{P} / \mathrm{S}, \mathrm{PT}$ & $\mathrm{SRP}$ & $\mathrm{AGT} / 6-24$ & MAP & -- \\
$\mathrm{T}$ & $\mathrm{t}-\mathrm{SRL}$ & -- & $\mathrm{SRT}$ & $\mathrm{AGT} / 6-24$ & $\mathrm{MAT}$ & $\mathrm{ITD}$ \\
$\mathrm{S}$ & $\mathrm{s}-\mathrm{SRL}$ & $\mathrm{S} / \mathrm{T}$ & $\mathrm{SRS}$ & $\mathrm{AGT} / 5-6$ & $\mathrm{MAS}$ & $\mathrm{ATD}$ \\
\hline
\end{tabular}

P, S, T: primary, secondary and tertiary stem cells; SRP, SRS, SRT, self-renewing D1 cells belonging to the p-SRL, s-SRL, t-SRL stem cell lines; MAP and MAT cells, mitotic arrested D2 cells produced by the p-SRL and t-SRL stem cell lines; MAS: Mitotic arrested D2 cells produced by the s-SRL stem cell line; ITD: Induced terminal differentiation producing ITD cysts; ATD: Autonomous terminal differentiation (ATD cysts); AGT: Average generation time

division by an arithmetical progression [3]. At $t=96$ the primary population in the Figure 1 contains $85.70 \%$ MAP $\left(\geq 4.8 \times 10^{6}\right.$ cells) and only $14,39 \%$ SRP cells ( $\geq 0.8 \times 10^{6}$ cells). The ratio is 1:6 (Table 2).

\section{Oxidative stress by stirring and homogenisation}

The homogenisation of the culture sediment at $\mathrm{t}=96$ (SARC) t96) and the oxidative stress caused by homogenisation stops $\mathrm{p}$-SRL proliferation. After re-centrifugation, the culture in the Table 2 (sample 2) contains only few residual bacteria and these bacteria were already exposed for $96 \mathrm{~h}$ to antibiotic pressure and amoebic exoenzymes. However, the low hypoxia following SARC/t96 promotes the primary SRP cells of the $6^{\text {th }}$ generation ( $\mathrm{D} 1{ }^{6}$ cells) into $\mathrm{P} / \mathrm{S}$ conversion, shifting them to predecessor cells for the secondary s-SRL. After the conversion secondary SRS cells (D17,8 cells) cycled by AGT6 and produce MAS cells for oxygenic terminal differentiation (ATD) and cyclic encystment (CE). The primary culture ends at $t=120$ as a heterologous population containing $66.6 \%$ primary MAP cells (D2 $\left.{ }^{1-6}\right), 22.2 \%$ ATD cysts (D2 $\left.{ }^{7,8}\right)$ and $11.1 \%$ secondary SRS cells $\left(D 1^{8}\right)$ (Figure 2 ). These findings characterized the secondary s-SRL line as a more oxygenic stem cell line (MO line), starting and proliferating in low hypoxic environments. It is a crucial divergence between the response of cycling and quiescent $P$ cells at SARC/t96. While SRP cells go into the P/S conversion MAP cells (that have the role of reserve stem cells $\mathrm{RSC}$ ) remain unaffected and do not take part in it. In the reestablished $96 \mathrm{~h}$ culture sediment MAP cells don't found stimuli for mitotic reactivation. Missing appropriate signalling cues, pre-stationary MAP cells do not escape mitotic quiescence. They remained arrested at the GO checkpoint for $R S C$ reactivation and cell cycle re-entry (II), waiting for the appropriate stimuli. Similarly, mitotic arrested cells in $48 \mathrm{~h}-72 \mathrm{~h}$ old subcultures remain unaffected by SARC/t48 and SARC/t72 (Table 3). While $\mathrm{P} / \mathrm{S}$ conversion may occur oxygenically, MAP reactivation is refractory to the simple oxygenation of older cultures.

\section{Are P/S conversion stimuli by SARC/t96 exclusively achieved by residual $O C B$ ?}

At t96 the primary culture contains $5.6 \times 10^{6}$ vegetative cells. $85.61 \%$ of the cells are MAPs and $14.39 \%$ SRPs. However, the MAP cell fraction contains cells are different in age: the last

Table 2. Growth of the primary culture in sediments with oxygen consuming bacteria.

\begin{tabular}{llllllllll}
\hline Time in h (event) & $\begin{array}{l}\text { ITD } \\
\text { cysts }\end{array}$ & $\begin{array}{l}\text { Metacystic } \\
\text { amebulae (A) }\end{array}$ & $\begin{array}{l}\text { Vegetative } \\
\text { amoebae (V) }\end{array}$ & $\begin{array}{l}\text { SRP cells } \\
(\mathbf{p}-S R L)\end{array}$ & $\begin{array}{l}\text { MAP } \\
\text { cells }\end{array}$ & $\begin{array}{l}\text { SRS cells } \\
(\mathbf{s}-S R L)\end{array}$ & $\begin{array}{l}\text { ATD } \\
\text { cysts }\end{array}$ & $\begin{array}{l}\text { Cell } \\
\text { divisions }\end{array}$ & $\begin{array}{l}\text { Ratio } \\
\text { A:V }\end{array}$ \\
\hline t0 (start) & $\geq 0.1$ & -- & -- & -- & -- & -- & -- & -- & -- \\
Excysment & -- & $\geq 0.8$ & -- & -- & -- & -- & -- & -- & -- \\
t96 $\left(1^{\text {st }}\right.$ counting) & -- & -- & 5.68 & $\geq 0.8$ & $\geq 4.8$ & -- & -- & 6 & $1: 7$ \\
t120 $\left(2^{\text {nd }}\right.$ counting) & -- & -- & 5.76 & -- & $\geq 4.8$ & $\geq 0.8$ & 1.7 & $6+2$ & $1: 7$ \\
\hline
\end{tabular}

Cell fractions in $10^{6}$ units. Approximately $0.1 \times 10^{6}$ ITD cysts induced by AaEM encystment medium were added to an $\mathrm{Aa}(\mathrm{Sm})$ culture of $5 \mathrm{ml}$ medium and $5 \mathrm{mg}$ metabolically repressed OCB. To minimize oxidative stress by stirring, counting and re-sedimentation (SARC), samples were counted only toward the end of the growth phase (t96). After ex-cystment $\geq 0.8 \times 10^{6}$ metacystic amebulae (A cells) started the primary p-SRL by A/P conversion. Amoebic population increased by arithmetic progression and asymmetric cell division producing non-identical D1 and D2 daughter cells. At $t 961 / 7$ of the population $\left(\geq 0.8 \times 10^{6}\right)$ belongs to the cycling self-renewing p-SRL line in the sixth generation (D $1^{6}$ cells). The other six parts $\left(\geq 4.8 \times 10^{6}\right.$ cells) are MAT cells (D2 ${ }^{1-6}$ cells) accumulated in the quiescent stem cell reservoir. They remain mitoticly repressed until the end of the culture, yet retain phagocytic activity.

SARC/t96 leads p-SRL line to P/S-conversion, starting the secondary s-SRL stem cell line. The s-SRL line remains numerically unchanged $\left(\geq 0.8 \times 10^{6}\right.$ cells). During the time $\mathrm{t}=96$ until $\mathrm{t}=120$ it goes through two cell cycles. Two additional generations of MAS cells $\left(\mathrm{D} 2^{7-8}\right)$ give rise to ATD cysts by autonomous terminal differentiation. The primary culture becomes heterogeneous. At $\mathrm{t}=120$ it contains $\geq 4.8 \times 10^{6}$ primary MAP cells (D2 $2^{1-6}$ cells), $\geq 0.8 \times 10^{6}$ self renewing secondary SRS cells (D1 ${ }^{8}$ cells) and $1.7 \times 10^{6}$ ATD cysts (encysted MAS, D2 ${ }^{7-8}$ cells). The primary p-SRL line proliferates by AGT $\leq 15$ while the secondary s-SRL line by AGT6. 


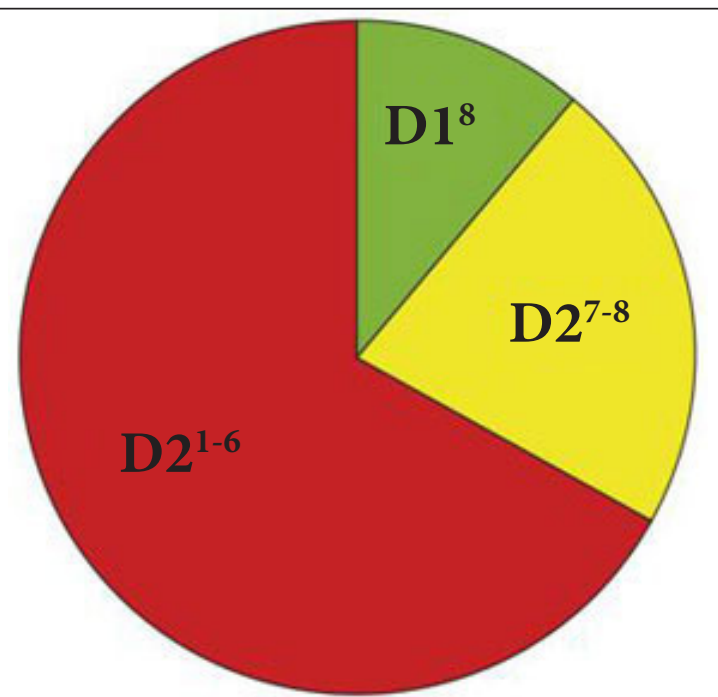

Figure 2. SARC/t96 conversed self-renewing primary SRP cells (D1 ${ }^{6}$ cells) into a secondary s-SRL stem cell line.

The 120 h old primary culture from the Table 1 contains a total of eight cell generations by asymmetric cell divisions. Red represents the six generations of mitotic arrested primary cells MAP/D2 $2^{1-6}(66.6 \%)$, yelow the two generations of ATD cysts (22.2\%) formed by the secondary MAS/D27-8 cells and green the cycling SRS/ $\mathrm{D} 1^{8}$ stem cells of the secondary s-SRL line (11.1\%).

generation of cells such as MAP/D2 ${ }^{6}$ cells are only a few hours old while the first generation of MAP/D2 ${ }^{1}$ cells are of about $80 \mathrm{~h}$ old. Aging MAPs doubled or trebled their cell volume to giant cells. Due to their ever-increasing cell surface and the higher number of receptors old MAP cells phagocytose the largest share of sediment bacteria. The question is: (i) are the few residual bacteria after 4 days of exposure to antibiotics and amoebic exoenzymes still capable of consuming sufficient oxygen from the reformed culture sediment, to produce conditions for P/S conversion, s-SRL proliferation and oxygenic ATD encystment, or (ii) is the weak oxygen reduction after $\mathrm{t}=96$ largely caused by amoebic oxygen defence mechanisms? Genes and proteins related to the oxidative stress response were frequently reported in Entamoebae [17,20-23] and Giardia $[\mathbf{2 4 , 2 5}$. Detoxifying enzymes such as NADH oxidase are expected to reduce oxygen to water $[17,25]$ and $\mathrm{H}_{2} \mathrm{O}_{2}$ produced by amoebic flavoproteins seem to be inactivated by other obscure mechanisms and detoxifying enzymes [26]. On the other side it could be assumed that the weak hypoxia restored after SARC/t96 goes to the account of both participants in the culture sediment, namely the $5.6 \times 10^{6}$ amoebic cells and the residual bacteria used as food particles for the secondary SR cells (SRS/D 1,8).

\section{Subcultures}

Starting sediments induce $P / S$ and $P / T$ cell conversion Before transfer, $\mathrm{P}$ cells grown in the protective hypoxic sediment of the primary culture were suspended in the supernatant column, homogenized and triple counted. During this time (10-15 $\mathrm{min}) \mathrm{P}$ cells were exposed to the native DO content of the culture medium $\left(8.1 \% \mathrm{O}_{2}\right.$ content). The oxidative stress continues in the sediment of the subculture as long as oxygen consumption by OCB is low. Culture passage is in fact a SARC/t0 event.

In contrast to SARC/t96, SARC/t0 induces both SRP and MAP cell fractions into cell conversion. The type of conversion depends on the oxygen depletion and hypoxia dynamics during the early initiation phase INI. Oxygen consumption depends both on the metabolic efficiency of the new OCB sediment and the phagocytic activity of the amoebic inoculum. Less oxygen depletion generates more oxygenic niches (MO niches), stronger oxygen consumption more hypoxic niches (moderate $\mathrm{MH}$ niches). $\mathrm{OCB} / \mathrm{MO}$ niches enable $\mathrm{P} / \mathrm{S}$ conversion (sample $3 a$ ) while $\mathrm{OCB} / \mathrm{MH}$ niches enable $\mathrm{P} / \mathrm{T}$ conversion (sample 3b-3c) (Table 3).

Converted predecessor cells for the secondary and tertiary stem cell lines (PDS and PDT cells) end the current cycle and divide asymmetrically in the late initiation phase (t2-t4). The secondary s-SRL line is an oxygenic non-continuous line living in $\mathrm{OCB} / \mathrm{MO}$ niches. It produces MAS cells capable to differentiate autonomously to ATD cysts via endopolyploidization and oxygenic terminal differentiation [123]. In unfavorable hypoxic conditions SRS cells converts to T stem cells by S/T conversion (sample 3a). The tertiary t-SRL line is a unipotent continuous line proliferating in vitro infinitely (immortal stem cell line). It is a ubiquitous MO/MH stem cell line producing invasive MAT cells. MATs are capable for hypoxic ITD encystment. All stem cells and stem cell lines are presented in Table 1.

\section{Reserve stem cells reactivation}

Primary MAP cells play the role of pluripotent reserve stem cells (RSCs) and could be reactivated by passaging to subcultures. In contrast to the state of nutrient depletion at the end of the primary culture (t96-t120), subcultures get fresh OCB not affected by antibiotics and exo-enzymes, fresh nutrients and bovine serum. The nutrient rich environment stimulates MAP cells for reactivation. They pass the G0 checkpoint for RSC reactivation and cell cycle reentry (II) replenishing the $p-S R L$ line. SARC/t0 returns MAP cells to undifferentiated cycling SRPs. MAP reactivation takes place in all samples from the Tables 3-5, independent of which bacterial dose we used (5-15mg).

Mitotic quiescent cells such as MAPs and MATs are reversible-differentiated cells [4]. Their reactivation for cell cycle re-entry is in fact a process of de-differentiation Responsible for checkpoint transition are environmental stimuli activating the genes for cell cycle re-entry. But where do these factors come from? In other cell systems such as ESC reactivation occurs by a serum response factor (SRF) [27]. Other researchers described de-differentiation as occurring under hypoxic conditions [28]. Definitively, RSC reactivation in E. invadens is by no means oxygenic. Primary MAPs were 
Vladimir F. Niculescu, Stem Cell Biology and Research 2015,

http://www.hoajonline.com/journals/pdf/2054-717X-2-2.pdf

doi: $10.7243 / 2054-717 \mathrm{X}-2-2$

Table 3. Hypoxia dynamics in the early initiation phase INI controls P cells conversion and select a unique proliferation pattern not influenced by the later natural hypoxic development in culture.

\begin{tabular}{|c|c|c|c|c|c|c|c|c|c|c|}
\hline Sample & OCB sediment & $\begin{array}{l}\text { Counting } \\
\text { Time (h) }\end{array}$ & ATD cysts & $\mathrm{T}$ cells & $\begin{array}{l}\text { Cell } \\
\text { conversion }\end{array}$ & $\begin{array}{l}\text { Encysted } \\
\text { MAS }\end{array}$ & $\begin{array}{l}\text { MAT } \\
\text { cells }\end{array}$ & $\begin{array}{l}\text { SRT cells } \\
\text { (t-SRL) }\end{array}$ & AGT & $n(t)$ \\
\hline \multirow[t]{2}{*}{$3 a$} & $\mathrm{OCB} / \mathrm{MO}$ & 36 & 4.08 & 3.06 & $\mathrm{P} / \mathrm{S}, \mathrm{S} / \mathrm{T}$ & $\mathrm{D} 2^{1-4}$ & $\mathrm{D} 2^{5-6}$ & $\mathrm{D} 1^{6}$ & AGT/5-6 & $6(36)$ \\
\hline & & $60^{* *}$ & 4.08 & 3.96 & -- & $\mathrm{D} 2^{1-4}$ & $\mathrm{D} 2^{5-7}$ & $\mathrm{D} 1^{7}$ & AGT/24 & $1(24$ \\
\hline \multirow[t]{2}{*}{$3 b$} & $\mathrm{OCB} / \mathrm{MH}$ & 24 & -- & 2.76 & $\mathrm{P} / \mathrm{T}$ & -- & $\mathrm{D} 2^{1}$ & $\mathrm{D} 1^{1}$ & AGT/24 & $1(24)$ \\
\hline & & $36^{*}$ & -- & 5.22 & -- & -- & $\mathrm{D} 2^{1-3}$ & $\mathrm{D} 1^{3}$ & AGT/6 & $2(12)$ \\
\hline \multirow[t]{2}{*}{$3 c$} & $\mathrm{OCB} / \mathrm{MH}$ & 48 & -- & 3.12 & $\mathrm{P} / \mathrm{T}$ & -- & $\mathrm{D} 2^{1-2}$ & $\mathrm{D} 1^{2}$ & AGT/24 & $2(48)$ \\
\hline & & $60^{*}$ & -- & 4.56 & -- & -- & $\mathrm{D} 2^{1-3}$ & $\mathrm{D} 1^{3}$ & AGT/11-12 & $1(12)$ \\
\hline
\end{tabular}

Cell fractions in $10^{6}$ units. The average generation time AGT was estimated by the equation AGT=t:n. In this equation " $\mathrm{t}$ " is the population age at the moment of counting and " $n$ " the number of cell divisions performed by cycling cells. The average generation time AGT is a real indicator for niche quality and cycling cell response.

Parallel cultures (samples 3a-3c) were started with $1.02 \times 10^{6}$ (sample 3a), $1.04 \times 10^{6}$ (sample 3c) and $1.28 \times 10^{6}$ (sample $3 \mathrm{~b}$ ) P cells and using a $5 \mathrm{mg}$ OCB dose by SARC/t0. First counting occurred at t24 (sample 3b), t36 (sample 3a) and t48 (sample 3c). After measuring, bottom sediments were restored by re-centrifugation (SARC). Re-evaluation occurred $12 \mathrm{~h}^{*}$ or $24 \mathrm{~h}^{* *}$ later. The fate of each culture was different, depending on the range of hypoxia developed by the OCB sediment during the early initiation phase INI ( $\mathrm{t} 0$ - $\mathrm{t} 2$ ). The most oxidative $\mathrm{MO}$ sediment in the sample $3 \mathrm{a}$ induces P/S conversion and fast cycling (AGT6) while the most hypoxic MH sediments in the samples 3b-3c decided for P/T conversion and slow cycling (AGT24). Culture sediments in the samples $3 \mathrm{a}-3 \mathrm{c}$ pointed out the preferences of the more oxygenic s-SRL and more hypoxic t-SRL stem cell lines for different hypoxic niches and pO2 levels.

Table 4. T cell proliferation in $\mathrm{OCB} / \mathrm{MO}$ sediments.

\begin{tabular}{lllllll}
\hline Sample & Counting time $^{*}$ & T cells (SRT, MAT) & SRT/(D1) cells & MAT/D2 ${ }^{1-2}$ cell & MAT/D2 ${ }^{2}$ cells & MAT cells \% \\
\hline Inoculum & 0 & 2.77 & -- & -- & -- & -- \\
$4 \mathrm{a}$ & 175 & 4.15 & 2.77 & 1.38 & -- & 60.50 \\
$4 \mathrm{~b}$ & 250 & 5.58 & $\mathrm{D} 2$ & 2.81 & -- & 100.00 \\
$4 \mathrm{c}$ & 450 & 5.54 & $\mathrm{D} 2$ & 2.77 & -- & 98.93 \\
$4 \mathrm{~d}$ & 490 & 6.59 & $\mathrm{D} 2$ & 3.82 & 1.01 & 133.10 \\
$4 \mathrm{e}$ & 530 & 7.95 & $\mathrm{D} 2$ & 5.18 & 2.37 & 179.72 \\
$4 \mathrm{f}$ & 625 & 8.59 & $\mathrm{D} 2$ & 5.82 & 3.01 & 200.00 \\
\hline
\end{tabular}

Cell fractions in $10^{6}$ units, counting time* in minutes. Parallel cultures (samples $4 \mathrm{a}-4 \mathrm{f}$ ) were started with $2.77 \times 10^{6} \mathrm{~T}$ cells in sediments with $5 \mathrm{mg}$ OCB. The high amoebic inoculum more rapidly consumes bacteria, generating an early $\mathrm{OCB} / \mathrm{MO}$ niche. T cells end current cell cycle in about $4 \mathrm{~h}(\mathrm{t} 250)$ and proliferate between $\mathrm{t} 250 \mathrm{an} \mathrm{d}$ t625 by fast cycling (AGT6).

negative to SARC/t96 and tertiary MAT cells in subcultures were also refractory to SARC/t24 and SARC/48 oxygenation (Table 3). On the other side MAT cells were induced to reactivation and T/ISH conversion by strong hypoxic OCB sediments (Table 5).

Mitotic reactivation of MAP and MAT cells occurs by SARC/t0 and cell transfer in fresh culture medium enriched by bovine serum. Similar oxygenation and low hypoxic ranges occurs in OCB sediments after SARC/t24, SARC/t48 and SARC/t72 however, cells remain unaffected and quiescent. Oxygenation alone does not seem sufficient for mitotic reactivation. Most probably, both SRF and low hypoxia cooperate for cell mitotic reactivation, checkpoint transition and cell cycle re-entry.

\section{S/T conversion}

$24 \mathrm{~h}$ after $\mathrm{P} / \mathrm{S}$ conversion hypoxia dynamics in the sample $3 \mathrm{a}$ (Table 3 ) stopped s-SRL proliferation and converted secondary
SRS cells into precursor cells for a t-SRL line. These findings show s-SRL line as a non-continuous stem cell line living exclusively in low hypoxic OCB/MO niches that start AGT6 proliferation. This line ends when oxygen consumption oversteps the metabolic limit of S cells. The subsequent t-SRL line retains AGT6 proliferation going in the following $12 \mathrm{~h}$ through two cell cycles (SRT/D1 ${ }^{7,8}$ ). The six generations of cells proliferating between $\mathrm{t}=0$ and $\mathrm{t}=36$ by fast cycling (SRS/D $1^{1-6}$ ) consumed the most of the OCB sediment replacing SRT cells in an unfavorable OCB niche. Lacking optimal conditions, the tertiary t-SRL line switched to AGT24. This decision occurred at a switching point for fast or slow cell cycling (III).

\section{Reprogramming cell proliferation}

Following $\mathrm{P} / \mathrm{S}$ or $\mathrm{P} / \mathrm{T}$ conversion by SARC/t0 (Table 3 ) cycling $\mathrm{S}$ and $\mathrm{T}$ cells decides for an adequate proliferation pattern. 
Table 5. T cell behaviour in MO, MH and SH bottom sediments and their capacity for induced terminal differentiation.

\begin{tabular}{|c|c|c|c|c|c|c|c|c|c|}
\hline Sample no. & $\begin{array}{l}\text { OCB } \\
\text { dose (mg) }\end{array}$ & $\begin{array}{l}\text { Counting } \\
\text { time (h) }\end{array}$ & $\begin{array}{l}\text { T cells } \\
\text { (D1+D2) }\end{array}$ & $\begin{array}{l}\text { Cell divisions } \\
\text { (A/S) }\end{array}$ & $\begin{array}{l}\text { Slow-fast } \\
\text { cycling }\end{array}$ & $\begin{array}{l}\text { MAT cells } \\
\text { (D2) }\end{array}$ & $\begin{array}{l}\text { ITD } \\
\text { cysts }\end{array}$ & $\begin{array}{l}\text { ITD } \\
\text { cysts \% }\end{array}$ & $\begin{array}{l}\text { Refractory } \\
\text { to ITD }\end{array}$ \\
\hline $5 a$ & 5 & 12 & 5.2 & $1(\mathrm{~A})$ & -- & $\mathrm{D} 2^{1}$ & 4.37 & 84 & -- \\
\hline $5 b^{(1)}$ & -- & 18 & 7.6 & $2(\mathrm{~A})$ & fast & $\mathrm{D} 2^{1-2}$ & 4.71 & 62 & $\mathrm{D} 1^{3}$ \\
\hline $5 c^{(1)}$ & -- & 36 & 15.2 & $5(\mathrm{~A})$ & fast & $\mathrm{D} 2^{1-5}$ & 15.21 & 100 & -- \\
\hline $5 d$ & -- & 48 & 18.8 & $6(\mathrm{~A})$ & -- & $\mathrm{D} 2^{1-6}$ & 17.86 & 95 & -- \\
\hline $5 e^{(2)}$ & 10 & 48 & 13.2 & $4(\mathrm{~A})$ & intermediate & $\mathrm{D} 2^{1-4}$ & 10.56 & 80 & $\mathrm{D} 1^{4}$ \\
\hline $5 f^{(2)}$ & -- & 60 & 15.6 & $5(\mathrm{~A})$ & -- & $\mathrm{D} 2^{1-5}$ & n.d. & -- & -- \\
\hline $5 g^{(3)}$ & 15 & 48 & 6.0 & $1(\mathrm{~S})$ & slow & ISH & 12.08 & 200 & -- \\
\hline $5 \mathrm{~h}$ & -- & 72 & 17.2 & $1(\mathrm{~S})+2(\mathrm{~A})$ & -- & $\mathrm{D} 2^{2-3}$ & 0.32 & 80 & -- \\
\hline
\end{tabular}

Cell fractions in $10^{5}$ units; S, symmetric division; A, asymmetric division Parallel subcultures were started with a low amoebic inoculum of about $1 / 4$ of the standard amoebic inoculum $\left(2.60 \times 10^{5} \mathrm{~T}\right.$ cells). OCB used in these experiments are metabolically different from OCB in the table 3 and 4 . Samples $5 \mathrm{a}-5 \mathrm{~d}$ receive the standard OCB dose of $5 \mathrm{mg}$, samples $5 \mathrm{e}-5 \mathrm{f}$ the doubled and samples $5 \mathrm{~g}-5 \mathrm{~h}$ the tripled bacterial dose. All cultures were evaluated only once.

In cultures with $5 \mathrm{mg}$ OCB, T cells end current cell cycle and divide at the end of the initiation phase INI at about $t 4$. Thereafter, the t-SRL lines of the sample $5 \mathrm{~b} / 5 \mathrm{c}$ proliferate by fast cycling (AGT:6.2-7.2 $\mathrm{h}$ ). In cultures with the doubled bacterial dose of $10 \mathrm{mg}$ (sample 5e/5f) the t-SRL line proliferates with moderate AGT values (AGT11-12). The strong hypoxia which developed in culture sediments with $15 \mathrm{mg}$ OCB (samples $5 \mathrm{~g}$-5h) converted $\mathrm{T}$ cell progeny into symmetric cell fate. T cells converted to ISH cells. ISH cells progress cell cycle slowly and remain arrested at checkpoint for T cell re-conversion. Between $\mathrm{t} 48$ and $\mathrm{t} 72$ ISH cells return to asymmetric cell fate and AGT11.

ISH and MAT (D2) cells are capable for induced strong hypoxic terminal differentiation. Both cell types give rise in strong hypoxic OCB sediments and AaEM encystment medium to ITD cysts. Self-renewing T cells (D1) cells may be induced only in the early G1 phase (samples $5 c, 5 \mathrm{~d}$ ) so long as they are in a state of double potency and not mitoticly determined. When mitoticly determined they become refractory to encystment stimuli (samples 5b, 5e).

Secondary SRS cells decided in our attempts for fast cycling, while tertiary SRT cells switch in an environment-dependent manner. After $\mathrm{P} / \mathrm{T}$ conversion the OCB/MH niche from the samples $3 b, 3 c$ decide for slow cycling by AGT24. In contrast, the OCB/MO niche of the samples $4 \mathrm{a}-4 \mathrm{f}$ programmed AGT6 proliferation. Reprogramming does not occur in the sample $3 a$ after the natural S/T conversion. The t-SRL maintains the AGT6 proliferation pattern programmed by the $\mathrm{OCB} / \mathrm{MO}$ niche of the early initiation phase INI. The decision for slow or fast cycling depends on the hypoxic range of the OCB sediment during the early initiation phase INI (t0-t2) and remains constant for the whole culture growth phase.

During subsequent growth, reprogramming occurred only by SARC. SRT cells proliferating by AGT6 (sample 3a) switched by SARC/t36 to AGT24 and SRT cells cycling by AGT24 (sample 3b) switched by SARC/t24 to AGT6. Reprogramming depends on the oxygen content in the reformed OCB sediment. The hypoxic Gaussian curve of the reformed sediment is determinant for the new selected AGT pattern.

In other words, soon after passage, the OCB sediments from the samples $3 \mathrm{~b}$ and $3 \mathrm{c}$ becomes more hypoxic as the sediment of the sample $3 \mathrm{a}$, forming an OCB/MH niche. The low oxygen content repressed $\mathrm{P} / \mathrm{S}$ conversion thus favoring $\mathrm{P} / \mathrm{T}$ conversion and slow cycling. Until t24/t48 tertiary SRT cells maintain slow cycling, despite progressive OCB depletion and hypoxia weakening. SARC/t24 re-formed a more favorable $\mathrm{OCB} / \mathrm{MO}$ niche. Hypoxia developed by the OCB/MO niche switched cells from slow to fast cycling. $24 \mathrm{~h}$ later (t48) OCB depletion was more advanced and the reformed OCB sediment by SARC/t48 less favorable for switching.

In conclusion, oxidative stressors of the niche may perturb T cell proliferation and stop the current proliferation program. For an optimal AGT6 proliferation T cells need an optimal balanced OCB/MO niche. If this is not available $T$ cells choose metabolic pathways for fast cycling.

\section{$T$ cells and state of double potency}

As long as the T cell progeny (D1 and D2 cells) remain mitotic undetermined they are in a state of double potency and may differentiate terminally to ITD cysts. Both SRT in the early G1 phase and MAT cells in G0 state have ITD encystment ability and the T cell population encysts to $95 \%-100 \%$ (Table 5, samples 5c, 5d). In contrast, cells in the replicative S-phase can't differentiate and ITD encystment goes back to 2/3 (sample $5 b$ ) or $4 / 5$ (sample $5 e$ ). When induced for strong hypoxic ITD encystment MAT cells in the G2/M phases end the running cell cycle by a differentiative symmetric division and conversed to identical ISH cells. All ISH daughter cells may encyst and the apparent encystment ratio is $200 \%$ (sample $5 \mathrm{~g}$ ).

\section{Symmetric division and ISH cells}

The OCB dose of $15 \mathrm{mg}$ gives rise to a strong hypoxic OCB/ $\mathrm{SH}$ niche, that disturbed the fidelity of the asymmetric cell proliferation (sample $5 \mathrm{~g}-5 \mathrm{~h}$ ). T cells meeting the strong hypoxic $\mathrm{OCB} / \mathrm{SH}$ niche changed from asymmetric to symmetric cell fate. Switching occurs at a checkpoint for symmetric cell fate 
Vladimir F. Niculescu, Stem Cell Biology and Research 2015,

http://www.hoajonline.com/journals/pdf/2054-717X-2-2.pdf

(IV). Passaging this checkpoint, T cells divide by symmetric differentiative division to a new type of identical cells that proliferate exclusively in $\mathrm{SH}$ conditions (ISH cells) by extremely slow cycling. ISH cells continue to phagocytize OCB. $48 \mathrm{~h}$ after start amoebic phagocytosis diminished hypoxia and ISH cells arrest at the checkpoint for T cell return (V) awaiting the further metabolic development of the sediment (sample $5 \mathrm{~g}$ ). By further bacterial depletion the $\mathrm{OCB} / \mathrm{SH}$ niche becomes an OCB/MH niche and ISH cells re-convert to T cells and asymmetric cell fate (sample $5 \mathrm{~h}$ ). ISH cell transfer in nutrientfree AaEM encystment medium and strong hypoxic $\mathrm{OCB} / \mathrm{SH}$ niches results in symmetric differentiative division. The two identical ISH daughter cells (G1 cells) encyst to ITD cysts.

Symmetric stem cell renewal was recently described in human ASC [29-31]. Differentiative symmetric stem cell division was observed in hair follicle [32], intestinal epithelium [33], epidermis [34] and other human tissue [35]. Disruption of asymmetric division decoupled differentiation from proliferation [31]. ISH cells conserved the same basal mechanisms existing in the highly evolved mammalian stem cell systems.

\section{Multilined cultures}

As seen in primary cultures SARC/t96 induced oxidative stress leads to $\mathrm{P} / \mathrm{S}$ conversion and ATD cyst production (Figure 3). Passaging $\mathrm{P}$ cells at the time when the primary population contains only $\mathrm{P}$ cells $(\mathrm{t}<96)$, the subculture remains homogenous. However, the fate of the subculture depends on the OCB niche starting in the early INI ( $\mathrm{t} 0-\mathrm{t} 2)$. When an OCB/ $\mathrm{MH}$ niche is established, then $\mathrm{P}$ cells convert to a t-SRL line ( $\mathrm{P} / \mathrm{T}$ conversion) and the subsequent population is cyst-free and homogenous. When an OCB/MO niche is established, then $\mathrm{P}$ cells convert to a s-SRL line for ATD cysts production (P/S conversion). Later (t28) SRS cells convert to a t-SRL line and the subculture became heterogenous. The fate of the subculture depends both on the kind of amoebic inoculi (containing one or more cell types) and on the type of the starting $\mathrm{OCB}$ niche (MO, $\mathrm{MH}$ or $\mathrm{SH}$ niche).

As seen in the Table 6 some passages contain ATD cysts, others do not. Cyst free populations are not always homogenous. They may contain, in addition to the major $\mathrm{t}-\mathrm{SRL}$, a young primary $\mathrm{p}-\mathrm{SRL}$ generated by just hatched ATD cysts. $\mathrm{P} / \mathrm{S}$ conversion in the next passage gives rise to a secondary s-SRL line producing ATD cysts, but the transient s-SRL converts further to a tertiary t-SRL. At the end of the passage, the population contains two t-SRL lines and ATD cysts from the transient s-SRL.

\section{Discussion}

The discovery of $E$. invadens stem cell lineage in variable OCB niches using metabolically repressed bacteria provided an opportunity to study the biology of AnSC and also the evolutionary origin of stem cells. OCB sediments are outstanding instruments to study complex interrelations between

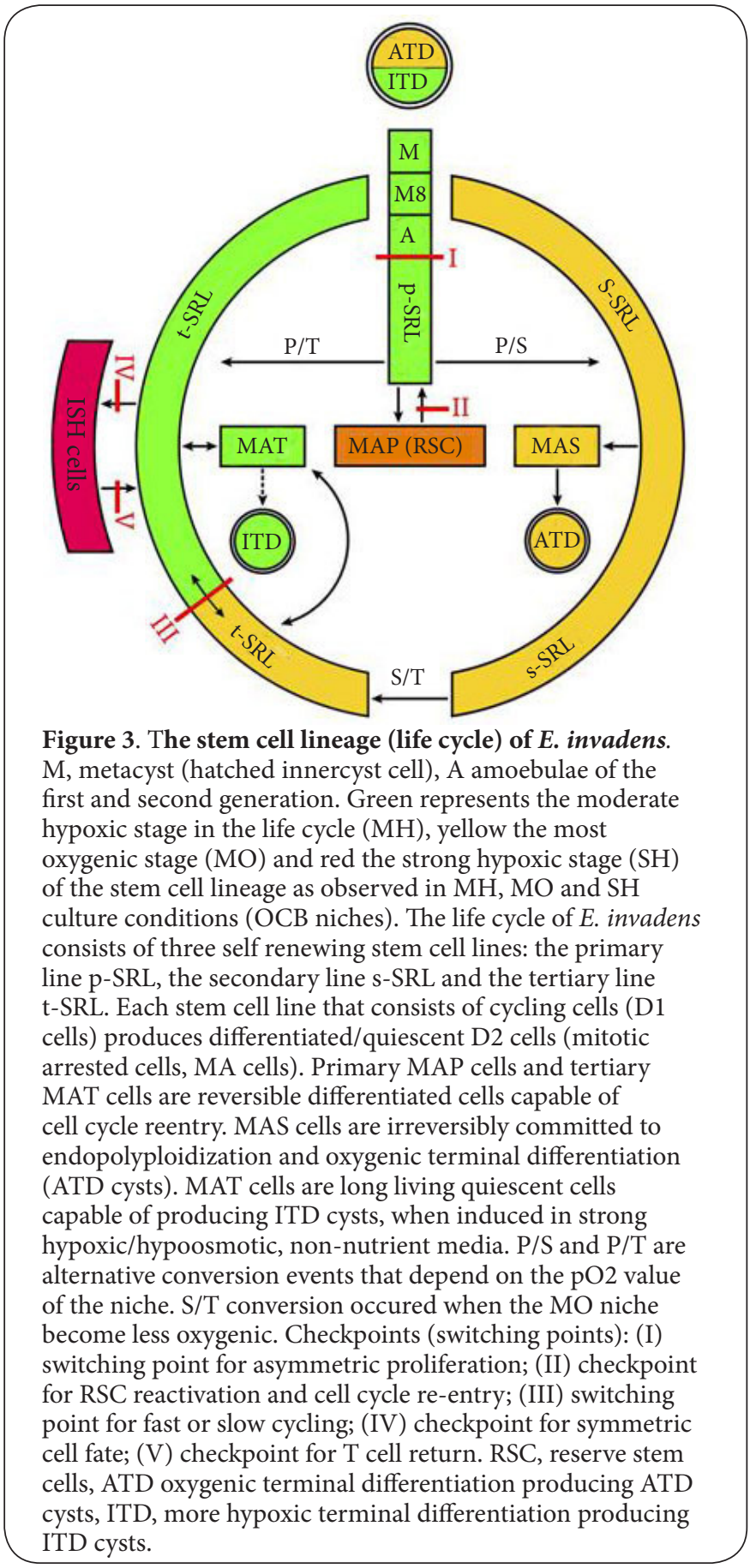

stemness and the hypoxia of the niche. While OCB sediments underlie amoebic phagocytosis they mimic all metabolic niches* of the host: from almost anoxic $\left(<0.1 \% \mathrm{O}_{2}\right)$ and strong hypoxic $\mathrm{SH}$ niches $\left(0-1 \% \mathrm{O}_{2}\right)$ to moderate hypoxic $\mathrm{MH}$ niches $\left(2 \%-5 \% \mathrm{O}_{2}\right)$ and moderate oxygenic $\mathrm{MO}$ niches $\left(5-8 \% \mathrm{O}_{2}\right)$. The oxygen contents of liver and intestinal tissue-both frequently infected by $E$. histolytica-are $5.4 \%$ respectively $7.6 \% \mathrm{O}_{2}[110]$. Like natural host niches, OCB niches control the development of Entamoeba's lineage and cell differentiation. 
Table 6. Stem cell conversions and multi-lined cultures.

\begin{tabular}{lllllll}
\hline Population & Case & Inoculum & $\begin{array}{l}\text { Conversion } \\
\text { (early INI) }\end{array}$ & $\begin{array}{l}\text { SARC during } \\
\text { growth }\end{array}$ & $\begin{array}{l}\text { Conversion } \\
\text { by SARC }\end{array}$ & End of culture \\
\hline Primary & A & ITD cysts & A/P & -- & -- & T \\
& B & ITD cysts & A/P & t96 & P/S & T+S+ATD cysts \\
Subcultures & C & P & P/T & -- & -- & T \\
& D & P & P/S, S/T & -- & -- & T+ATD cysts \\
& F & T+ATD cysts & A/P & -- & -- & T+P \\
& E & S+ATD cysts & A/P & -- & -- & P+T+ATD cysts \\
& G & P+T+ATD cysts & A/P, P/S & -- & -- & P+T+ATD cysts \\
& H & P+T+ATD cysts & A/P, P/T & -- & -- & P+T \\
& I & T+P & P/S, S/T & -- & -- & T+ATD cysts \\
& J & T+P & P/T & -- & -- & T \\
K & T & -- & -- & -- & T \\
\hline
\end{tabular}

Depending on the kind of inoculi, OCB niches and oxidative stress cultures end as homogenous, apparently homogenous and heterogenous populations. Only few populations are homogeneous consisting of a single stem cell type ( $\mathrm{P}$ or $\mathrm{T}$ cells). Apparently homogenous populations contain usually a dominant $\mathrm{T}$ cell subpopulation and a minor (coverted) $\mathrm{P}$ cell fraction respectively $\mathrm{S}$ cell fraction producing ATD cysts in the subsequent passage. This explains why some cultures contain cysts and others not. ATD encystment in cultures was defined in the past as an enigmatic "spontaneous" encystment.

${ }^{*} O C B$ niches are metabolic environments consuming oxygen. Environmental cues and niche hypoxia control E. invadens' stem cell lineage. For niche definition see Liu et al 2009 [79].

\section{Life cycle and stem cell lineage in $E$. invadens}

E. invadens' stem cell lineage has oxygenic, more hypoxic and strong hypoxic cell lines and a robust stem cell hierarchy. Lineage development begins with the eight metacystic amoebulae (A cells) generated by the hatched innercyst cell, that decide for stemness and asymmetric cell fate. It continues with the self-renewing $p-S R L, s-S R L$ and $t-S R L$ lines that give rise by asymmetric cell division to non-identical daughter cells. One is the self-renewing cell (D1 cell) and the other, the mitotic arrested cell (D2 cell).

Primary MAP cells are reserve stem cells (RSC). MAP cells are reversible differentiated cells [4] capable of reentering the cell cycle and converting to a subsidiary stem cell line (s-SRL, t-SRL). Secondary MAS cells are irreversibly committed for endopolyploidization by an oxygenic (intrinsic) mechanism of differentiation [123]. Endopolyploid MAS cells (MAS/EP cells) are induced by oxygenic stimuli to ATD encystment (ATD cysts). The dominant MAT subpopulation maintains phagocytical activity. It is the invasive cell type of E. invadens. MAT cells may be induced experimentally to convert to ITD cysts directly (as GO cells) or via ISH cell cycle and symmetric division. In contrast to ATD encystment, the mechanisms of ITD encystment are strict hypoxic and induced by extrinsic stimuli. In the past ATD cysts were falsely considered to occur "spontaneously".

According to their life duration both primary $p-S R L$ and tertiary t-SRL are non-continuous stem cell lines. The tertiary $\mathrm{t}-\mathrm{SRL}$ is the unique, continuous immortal stem cell, living infinitely in $\mathrm{MO}$ and $\mathrm{MH}$ niches. The secondary s-SRL is the unique stem cell line living exclusively in $\mathrm{OCB} / \mathrm{MO}$ niches. According to their conversion and differentiation capacities $\mathrm{P}$ cells are multipotent and $T$ cells unipotent. Potency restriction occurs during cell line conversion. Each SRL is constant in number and surrounded by a bulk of mitotic arrested cells. MAT cells are the most dominant cell subpopulation. In strict hypoxic OCB/SH niches T cells converted to strong hypoxic ISH cells which proliferate by slow cycling and symmetric division. ISH cells are transient amplifying stem cells of identical cell fate, living exclusively in strong hypoxic $\mathrm{OCB} / \mathrm{SH}$ niches in almost anoxic conditions. When oxygen content increases ISH/G2 cells arrest at the checkpoint for $T$ cell return $(V)$, waiting the further evolution of the niche. Oxygen depletion and return to strong $\mathrm{OCB} / \mathrm{SH}$ niche continues ISH cell proliferation. When hypoxia lessens then ISH cells reconvert to T cells. ISH/G2 cells transferred in $\mathrm{OCB} / \mathrm{SH}$ sediments and encystment medium give rise to two ISH/G1 daughters that form ITD cysts.

Five cell conversion events (A/P, P/S, S/T, P/T, T/ISH) and several checkpoints and switching points controlled lineage development in E. invadens. Cell conversion occurs by passaging and depends on hypoxic stimuli in the starting OCB sediment (Figure 3 ).

E. invadens' stem cell lineage ends by a terminal differentiation process that forms ATD or ITD cysts. Terminal differentiation includes totipotency recovery by molecular reprogramming. The resting innercyst cell is the totipotent progenitor capable of a new round of life. At the moment, it 
Vladimir F. Niculescu, Stem Cell Biology and Research 2015,

is unclear if the innercysts cells of the ITD and ATD cysts are in toto identical. Their vegetative descendants are not. MAS cells are short living cells committed to MAS/EP differentiation, while MAT cells are long living reversible-differentiated G0 cells capable of phagocytosis and invasiveness. ATD encystment is a more oxygenic process occurring in $\mathrm{OCB} / \mathrm{MO}$ sediments while ITD encystment is a strong hypoxic process occurring in $\mathrm{OCB} / \mathrm{SH}$ niches.

The oxygen content of OCB sediments and tissue specific niches are the determinants for lineage development. Starting $\mathrm{OCB} / \mathrm{MO}$ niches (subculture) leads primary SRP cells to P/S conversion and enables s-SRL line to produce ATD cysts. Once the OCB niche consumes more oxygen and become hypoxic, the s-SRL line stops proliferation and ATD cyst formation and converts to a tertiary t-SRL capable of proliferation in both $\mathrm{OCB} / \mathrm{MH}$ and $\mathrm{OCB} / \mathrm{MO}$ niches.

In the past, ITD encystment assays were performed on axenically grown trophozoites induced for encystment in nutrient poor encystment media named TPS, CEM or AEM $[36,37]$. AEM contains a triptic digest of casein, yeast extract and $5 \%$ dialyzed serum in $5 \mathrm{mM}$ potassium phosphate $\mathrm{pH} 7.0$. The terminal differentiation process takes about $30 \mathrm{~h}$. Using cells of the growth phase $70 \%$ of the cells encyst. Other researchers induced encystment in diluted (hypo-osmotic) growth medium or in growth medium without glucose [38], however, little is known about the state of environmental hypoxia encountered by the permissive and refractory cells. Turner and Eichinger [39] used horizontally incubated glassscrew-cap tubes full with an encystment medium containing $5 \%$ adult beef serum inoculated with a total of $4.5 \times 10^{6}$ cells $\left(5 \times 10^{5} \mathrm{cell} / \mathrm{ml}\right)$. They observed the formation of multicellular aggregates, within which encystment occurred and consider aggregates formation as the initial phase of encystment started by the Gal-terminated ligands from the serum. They proposed that "only those cells in contact with adsorbed ligands would be competent to encyst". The majority of aggregate cells-to which the adsorbed ligand are unavailable-would not be expected to encyst. By this method cells may take several days to complete encystment ( $>48 \mathrm{~h}$ ). In our opinion cells horizontally incubated in glass-screw-cap tubes need more time for consuming oxygen; the aggregates facilitate the hypoxic state needed for ITD encystment.

Our encystment study takes place in $\mathrm{OCB} / \mathrm{SH}$ bottom sediments covered by $5 \mathrm{ml}$ nutrient-free phosphate buffer in tubes incubated vertically at $26^{\circ} \mathrm{C}$. This method is superior to all previous methods and more effective. T cells encyst in about 10-12 $\mathrm{h}$ without additives, beef serum or ligands. Encystment efficiency depends on the cell cycle position of the induced cells: (i) T-cells in the state of double potency (non-differentiated SRT and MAT cells) may be induced directly for ITD encystment at the ratio 1:1 and encystment efficiency is $100 \%$; (ii) G1 cells passing restriction point RP are mitotic determined and not capable for ITD encystment; (iii) cells from the S-phase are refractory for encystment; and (iv) G2/M cells conversed to ISH cells, that end cell cycle by symmetric differentiative division giving rise to identical ISH daughter cells that both encyst (encystment efficiency 200\%-sample 5g).

As with the stem cells of ancestral divergents, AnSC cells of E. invadens are stages of the ancestral life cycle. Different cell types (life cycle stages) cohabitate within the cell community as single-celled individuals. They cooperate to model niche hypoxia changing the characteristics of metabolic OCB niche by phagocytosis (bacteria depletion), thus altering the oxygen content of the niche. Lineage development depends on hypoxia dynamics in the niche. In vivo parasitic AnSC live in inflammatory and non-inflammatory host niches, mimicking the behaviour of host stem cells that reside in native hypoxic niches.

The stem cell lineage of $E$. invadens is the most primitive stem cell system known today and evolutionarily closer related to LECA than any other stem cell system of basal metazoans. Stem cells and differentiation features of $E$. invadens are not consequences of the parasitic way of life. On the contrary, the parasitic way of life was made possible by the basal stem cell mechanisms inherited from LECA and conserved by Entamoeba [40].

\section{Energy metabolism and metabolic pathways of Entamoeba}

Similar to Giardia lamblia and Trichomonas vaginalis, Entamoebae are hypoxic eukaryotes capable of anaerobic energy metabolism [41]. Metabolic anaerobe protists lack features of aerobic metabolism such as the Krebs' cycle and oxidative phosphorylation. They have metabolites involved in glycolysis and associated pathways [42]. In Entamoeba L-cystein seem to be an important scavanger of reactive oxygen species. It plays an essential role in proliferation, adherence and defence against oxidative stress. L-cystein depletion leads to drastic changes in core metabolism. It represses glycolysis reducing the production of ethanol and the major nucleotitide di- and tri-phosphates [42].

Entamoebae consume oxygen and tolerate low levels of pO2 [42-44]. They are highly susceptible to exogenous reactive oxygen species (ROS) such as hydrogen peroxide and possess mechanisms of detoxification similar to those known in prokaryotes [44]. The end products of anaerobic metabolism are $\mathrm{CO}_{2}$ ethanol and acetate. Three times as much ethanol as acetate (3:1) was produced in anaerobic experiments. In aerobic conditions the ratio was reversed (1:3) [45]. Oxidative stress by $400 \mathrm{mM}$ of $\mathrm{H}_{2} \mathrm{O}_{2}$ showed $90 \%$ trophozoites remain viable [42]. The oxidative stress by $\mathrm{H}_{2} \mathrm{O}_{2}$ caused drastic modulation of metabolites involved in glycolysis, chitin biosynthesis, and nucleotide and amino acid metabolism. Oxidative stress leads to inhibition of glycolysis, inactivating several key enzymes. They re-direct the metabolic flux towards glycerol and chitin biosynthesis. An increase of anaerobic glycolysis of glucose is known in mammalian embryogenesis also. The authors above considered the glycerol biosynthetic pathway as a metabolic 
anti-oxydative defence system in E. histolytica. Mechanisms of oxygen resistance seemed likely to be acquired by LGT from prokaryotes. Increased reactive oxygen species (ROS) and nitrogen species (RNS) as response to oxygen-derived stress were observed in mammalian tissues at the site of inflammation due to bacterial-type oxygen and nitric oxide reductases [17]. Both are markedly increased upon oxygen exposure.

According to the study above, we suppose that stem cells of $E$. invadens change their metabolic pathway when transferred from $\mathrm{MO}$ to $\mathrm{MH}$ niches by decreasing acetate and increasing ethanol production. If this is correct, proliferation of the tertiary t-SRL line (SRT cells) by AGT5-6, AGT11-12 and AGT24 depends on genes and metabolic pathways that control fast and slow cycling proliferation. We suppose that fast cycling (starting in $\mathrm{OCB} / \mathrm{MO}$ niches) takes place by evolutionarily younger metabolic pathways that produce more acetate as end product, while slow cycling starting in $\mathrm{OCB} / \mathrm{MH}$ niches would be controlled by an older metabolic pathway producing more ethanol. In OCB/MO niches oxygen acts as a powerful degrader of organic compounds. Many of the hypoxic organisms that do not tolerate $\mathrm{O}_{2}$ benefit from moderate doses of $\mathrm{O}_{2}$ (http:// www.ucmp.berkeley.edu/precambrian/archean_hadean.php).

\section{Genes and oxidative response of Entamoeba}

The TR2/1 strain of $E$. invadens is a highly invasive pathogen strain isolated from snakes. Its pathogenic potential is determined by the ancestral life cycle conserved by this strain. Lineage development starts in the anaerobe intestinal lumen of the host ( $\mathrm{SH} / \mathrm{MH}$ environments) and continues in the more oxygenic tissue of the colon, where primary cells convert either into an s-SRL(MO) line for oxygenic ATD cysts formation or into a tertiary t-SRL(MH) line producing invasive MAT cells. t-SRL is the invasive stem cell line capable of proliferating in both $\mathrm{MO}$ and $\mathrm{MH}$ tissue, activating permanently specific metabolic and cycling pathways. Stem cell responses to oxidative and hypoxic stressors are controlled by genes modulating lineage development.

Before stemness and stem cell lineages were discovered in $E$. invadens [3] and Giardia [4] numerous researchers held true the premise that the resistance of $E$ histolytica to ROS cytotoxicity is the determinant factor for pathogenicity [17]. The idea was that upon invasion of the intestinal epithelium metabolic anaerobe protists such as E. invadens and E. histolytica are confronted with varying $\mathrm{pO} 2$ values and cytotoxic reactive oxygen and nitrogen species (ROS and RNS). Genes coding for detoxification pathways for ROS and RNS were found in the genome of anaerobic protists [17]. Some of these genes had been acquired by LGT from prokaryotes $[116,117]$. The question was if the defense mechanisms against oxidative stress are induced at the time Entamoebae enters high oxygenic environments or not. To determine the oxidative pathway genes response, the highly invasive/pathogenic strain HM-1:IMSS was exposed to $1 \mathrm{mM} \mathrm{H}_{2} \mathrm{O}_{2}$ for 1 hour [17].
This $\mathrm{H}_{2} \mathrm{O}_{2}$ concentration approximates the physiological conditions of the gastrointestinal lumen [118]. Results from $\mathrm{H}_{2} \mathrm{O}_{2}$ exposed cultures were compared with control data from cells grown axenically there were not exposed to $\mathrm{H}_{2} \mathrm{O}_{2}$. The majority of genes encoding for ROS stress detoxifying proteins (ca 287 genes) were not significantly changed in cell exposed to oxidative stress [17]. The authors found 185 genes up-regulated by oxidative stress and and 102 genes down-regulated by $\mathrm{H}_{2} \mathrm{O}_{2}$ exposure. A significant number of genes code for unknown proteins. The largest group of genes up-regulated by $\mathrm{H}_{2} \mathrm{O}_{2}$ encodes proteins that may be related to signaling pathways and signaling/regulatory systems. The authors conclude that the transcriptional response at the detoxification level is constitutive for E. histolytica and was not induced by the $\mathrm{H}_{2} \mathrm{O}_{2}$ stressor.

We suppose that axenic culture medium offers a more oxygenic (MO) than a more hypoxic $(\mathrm{MH})$ environment and that axenically grown Entamoebae belong to a predominant T cell population, respectively, a t-SRL line adapted to low hypoxic conditions. Oxygen content in media at $37^{\circ} \mathrm{C}$ warm media is of about $6.71 \% \mathrm{O}_{2}{ }^{*}$. The fact that the majority of genes encoding ROS stress detoxifying proteins were not significantly changed when exposed to further oxidative stress might have something to do with the relative high $\mathrm{pO} 2$ value of the axenic culture.

*DO concentration at $37^{\circ} \mathrm{C}$ (http://water.epa.gov/type/rsl/ monitoring/vms52.cfm).

Non virulent (commensal) strains such as E. histolytica/Rahman and E.dispar were tested similarly. Only 218 genes were detected, 153 of which were upregulated and 65 downregulated by the $\mathrm{H}_{2} \mathrm{O}_{2}$ stressor. These strains are non-pathogenic (commensal) having probably a regressive evolution regarding the stem cell lineage. They have a significantly fewer transcriptional changes. Their overall number of changes for the regulating genes were significantly lower [17]. Both strains have a decreased repertoire of transcriptional changes in response to oxidative stress, the extent of up-regulation was much higher in the HM2:IMSS strain [17].

In contrast to the above results that proposed that differential response to oxidative stress is a primordial factor of the pathogenic potential of Entamoebae, we consider the fully conserved LECA protolineage to be the determinant for the invasive/pathogenic way of life. Strains and species which lack the whole ancestral stem cell protolineage and associated genes due to regressive evolution are non- invasive and non-virulent, living as commensals. A similar regressive gene evolution occurred in the kinom genetics of Giardia vs. ancient Excavata divergents [97].

Hypoxic ranges and environmental $\mathrm{pO} 2$ values modulate lineage development. Hypoxic stress controls $\mathrm{P} / \mathrm{T}$ and $\mathrm{S} / \mathrm{T}$ conversion, and slow cycling, while oxidative stress controls $\mathrm{P} / \mathrm{S}$ conversion and fast cycling. The secondary s-SRL (MO) prefers oxygenic environments while the tertiary t-SRL lives in both oxygenic and hypoxic niches. It proliferates in diverse 
Vladimir F. Niculescu, Stem Cell Biology and Research 2015,

http://www.hoajonline.com/journals/pdf/2054-717X-2-2.pdf

doi: 10.7243/2054-717X-2-2

MH niches by AGT24 or AGT11-12 and in MO environments by AGT5-6. The switching of T stem cells from slow to fast cycling is a major advantage for invasion and pathogenicity. Down- and up-regulating genes for still unknown proteins and cell control mechanisms are surely related to the metabolic processes occurring in the lineage by changing from $\mathrm{MH}$ into $\mathrm{MO}$ niches.

\section{Anaerobe and aerobe mitochondria in stem cells}

Cell metabolism mainly depends on mitochondria. Entamoebae contain between 25 und 150 mitosomes per cell [46,47]. Mitosomes and the dehydrogenosomes discovered in the last twenty years were considered mitochondrial "homologues" or "relic mitochondria". They were found in many metabolic anaerobe protists living in marine and fresh water sediments as well in protists living in commensal and parasitic symbiosis. Very little is known how mitosomes are inherited by cell division $[46,48,49]$.

All eukaryotic cells contain mitochondria and all mitochondria have an endosymbiotic origin [122]. However, the origin of endosymbiosys is highly controversial. The traditional view presumes an initial eukaryote-prokaryote endosymbiosis: the host acquiring this organelle would have been a full developed eukaryote, that phagocytized an obligate aerobe prokaryote mostly related to the modern day Rickettsiae [50]. This form of endosymbiosis would be a relatively late evolutionary event. Aerobe mitochondria use Krebs' metabolism that can be inhibited by hypoxia [46]. Thus, in strict hypoxic and parasitic life conditions the aerobe mitochondria would be undergone a dramatic reductive evolution to mitosomes. However, this traditional theory is problematic because it presumes the host cell to have been an eukaryote already. It cannot explain satisfactorily the ubiquity of mitochondria and some aspects of the reactive oxygen species problem [50]. A more recent theory preposes an early prokaryote-prokaryote endosymbiosis between a facultative anaerobe endosymbiont (a proteobacterium) able to live with or without $\mathrm{O}_{2}$-producing $\mathrm{H}_{2}$-and a prokaryote host (archaebacterium) that need $\mathrm{H}_{2}$ as a source of energy and electrons. The progressive evolution of such participants can better explain the eukaryotic ubiquity of mitochondria and the variety of anaerobic and aerobic mitochondria in eukaryotes [50]. Which theory best fits the stem cell reality? Undoubtedly, the prokaryote-prokaryote endosymbiosis.

Recent works take in to account the common ancestry of mitochondria, mitosomes and hydrogenosomes. The first metazoans which possessed cristae-mitochondria and a stem cell system lived in conditions of extremely low oxygen. Geochemical evidence points the general oxygenation of the oceans around 635 MYA [51,52]. A recent New Scientist blog* cites many authors saying that first animals evolved earlier, when there was a lot less oxygen. There are modern day sponges that survive for longer time in an aquarium with 200 times less oxygen then in the atmosphere indicating that early animals probably could too [51]. William Martin [50] pointed out that DNA today is so genetically diverse that the first animals must have evolved at a time when mitochondria in cells functioned without oxygen, similar to mitochondria from modern day sponges. Other paleontologists suggest that animals appeared even earlier, possibly as early as 1000 MYA [53].

*Colin Barras (2014) First animals may have lived with almost no oxygen. New scientist (Earth Science, Evolution, Featured, Life) 2014/02/17

Sponges are probably the earliest diverging extant metazoan [54-58] and the oxygen requirements of modern day sponges are still today extreme low $[\mathbf{5 9}, \mathbf{6 0}]$. The estimates suggest that early animals may have had relatively low oxygen requirements [51] and their stem cells contain probably more anaerobic than aerobic mitochondria. The mitochondria of archaeocytes and choanacytes have well defined cristae and and typical double membranes [61] however, they are rare and small in diameter ( 0.2 to $0.3 \mu$ ) [62]. In contrast, aerobe mitochondria from the free-living protist Tetrahymena pyriformis are larger (0.75-0.93 $\mu$ in diameter) and more numerous (900 units per cell) [63].

All these findings support the hypothesis that the first stem cell protolineage was developed by LECA at a time as the oceans has low to moderate oxygen contents and LECA has an anaerobe metabolism. As observed in E. invadens, stemness needs "proterozoic" conditions, namely hypoxic niches, glycolysis, anaerobic metabolisms and a low reactive oxygen species (ROS) content. All these standards are characteristics of the early anaerobic life of LECA passed down to protists and basal metazoans. The question is: what happens as metazoans become aerobes? How did these organisms adapt the ancestral stemness to their aerobic style of life?

Human stem cell researchers described over the last twenty years, stem cell systems as consisting of different subsets. A small stem cell subset would be necessary to sustain a steady state level of mature terminal differentiated cells and up-regulate their production in response to stressors and environmental cues [64]. The human HSC system needs a stem cell pool capable of cycling without pluripotency reduction, and a larger population of quiescent stem cells that cycle not more than sporadically and unpredictably. The hierarchical organization of the HSC system occurs on the basis of G0 quiescence, in which "primitive" haematopoietic cells exhibit stem cell activity $[64,65]$. The same "subsets" exist in the ancient stem cell systems of E. invadens and Giardia [4], however, a fundamental contradiction exists. The undifferentiated cycling stem cells of humans and mammalian (D1 analogs) preserve glycolysis and the metabolism of the anaerobe ancestor, while quiescent G0 cells (D2 analogs) and progenitor cells switch to TCA (Krebs) cycle and oxydative phosphorylation.

Human HSC reside in hypoxic bone marrow niches (BM niches) containing 1.3-4.3\% oxygen [66-68] and give rise to distinct stem cell subsets by asymmetric cell division: one of them is the undifferentiated self renewing fraction of HSCs 
(D1 analogs), that lost most mitochondria and proliferate by fast cycling. The metabolic activity of the aerobe mitochondria dispersed in cycling HSC cells is low and cells recover energy by anaerobe glycolysis. Undifferentiated pluripotent ESCs use glycolisis too and require a high flux of glucose uptake [69-71]. Metabolism of cycling HSC has intermediates and end products, which indicate active glycolysis and upregulation of glycolysis enzymes [66]. The quiescent subset (D2 analogs) accumulates most mitochondria and switches to aerobic metabolism. It exits cell cycle as quiescent cells or progenitor cells in an either slow cycling state. High levels of mitochondrial ROS prime progenitor cells for differentiation, while low levels of ROS retain self-renewing capacity of HSC $[66,69,73]$. In contrast to $E$. invadens, fast-cycling means in the HSC system four to seven cell divisions in a time interval of 7 weeks, while slow-cycling means at least 12-14 weeks till first cell division occurs $[\mathbf{7 4 , 7 5 ]}$.

The metabolic profile of the HSCs differs from that of differentiated and committed progenitors cells and reflects the location of the cells in a hypoxic niche [76,77]. If metabolic reprogramming of quiescent and progenitor cells from oxydative phosphorylation to glycolysis is cleared, protection mechanisms against hypoxic damages remain to be clarified [66]. The reprogramming of somatic cells to pluripotency (iPSC) is also dependant on glycolysis and depends on the metabolic profile of the starting somatic cells. During reprogramming, an increase in specific glycolytic gene expression precedes the genes that regulate self renewing, suggesting that metabolic resetting has an early active role in the return to pluripotency $[71,78]$. Induced totipotency recovery for ITD encystment in $E$. invadens also requires strong hypoxic conditions. Human iPSC cells probably use ancestral mechanisms for reprogramming pluripotency.

Others such as in protist AnSC, slow proliferating HSC cells (D2 analogs) give rise to a sequence of differentiating progenitor cells that can replenish the terminal differentiated cells (blood cells) via expansion of HSC or progenitor cell populations by symmetric cell division, however without depleting stem cell quality [79-83]. It is the same basal mechanism observed in E. invadens via ISH cells. Stem cell maintenance is controlled by tumor supressor genes, oncogenes and p53 protein [79] and the life span of HSC can be limited in vivo by elevated ROS levels [85] Loss of p53 function increases intracellular ROS levels which leads to increased DNA damage [84]. Quiescence may protect the cells from ROS-dependant DNA damages [79].

\section{Oxygen gradients of metabolic niches}

In the last 5-6 years stem cell researchers demonstrated that low $\mathrm{pO} 2$ levels greatly influenced embryonic and adult stem cell biology $[\mathbf{6 8 , 8 6 , 8 7 ]}$. Moreover, previously unknown stem cells could be found in notoriously hypoxic niches such as the kidney medulla/papilla [88]. Several studies on long term HSC (LT- HSC) lead to a model in which the hypoxic character of the stem cell is determined by its position within the BM niche [67]. The metabolic state and the oxygen pressure of the niche direct cell proliferation in both HSC and AnSC stem cell systems. Oxygen gradients from $<1 \%$ to $8 \%$ were described in the neural stem cell niche [89]. In the haematopoietic stem cell niche oxygen concentration varies between $1 \%$ (osteoblast region) and $6 \%$ (blood vessel) [68,80]. Quiescent HSC positioned distal, activated HSC interproximal, and progenitor cells were positioned proximal to the oxidative blood vessel $[\mathbf{6 8 , 9 0 ]}$. Oxygen tension as low as $1 \%$ decrease cell proliferation, while oxygen tensions between 3-5\% have no effect on proliferation [91]. Many experimental results suggest that proliferation and quiescence may be regulated by the oxygen tension gradient of the niche. This supposition is also valid for the AnSCs, which evolved in $\mathrm{MH} / \mathrm{MO}$ and $\mathrm{MO}$ niches, switching from extended quiescence to rapid proliferation.

Another striking similarity between AnSC and LT-HSC is their capacity to migrate from a more hypoxic niche to a more oxygenic niche. Studies on transplanted murine HSC have shown that stem cells move away from the bone vessel region deep in the osteoblastic zone [92,93], suggesting that HSC tell us something about the metabolic state of the niche in which they reside. The metabolic state of the niche controls cell proliferation in both AnSC and HSC lineages. It is clear that the stem cell biology of $E$. invadens can answer some open questions about metazoans and humans cell biology.

\section{The proterozoic origin of stemness}

Basal mechanisms of stemness existing in all stem cell systems are meaningful evidence for the common origin of stem cells. In contrast to other opinions [94], we believe that pathogen protists such as Entamoeba and Giardia can reveal much about the evolutionary history of LECA and the origins of stemness. Some researchers still consider both protists as relics of relatives living in the earliest phase of eukaryotic divergence $[95,96]$. Analysis of protein kinase sequence data from Entamoeba and of Giardia supports this hypothesis.

LECA evolution occurred mainly during the Proterozoic age linked with the oxygenation of the atmosphere and ocean waters. Four biogeochemical stages [97] are of interest for understanding LECA's evolutionary history. They were over the time: (i) the reduced Archean stage ( 3.85 to 2.45 GYA) as the ocean-atmosphere system was essentially free of oxygen, containing only traces amounts of $\mathrm{O}_{2}$ by water photolysis and geochemical processes in the shallow oceans. Early cyanobacteria produced in Archean local oxygen oases, long before oxygen began to accumulate in the atmosphere. At the beginning of oxygenic photo-synthesis oxygen levels in the atmosphere remained low; reduction of substances as $\mathrm{H}_{2^{\prime}} \mathrm{CO}$, $\mathrm{H}_{2} \mathrm{~S}$ and $\mathrm{Fe}$, consumed the net production of $\mathrm{O}_{2}$. (ii) the stage of oxidized surface water and reduced deep ocean (2.45 GYA to $1.85 \mathrm{GYA}$ ) as the supply of reducible substances decreased, oxygen began to accumulate in the atmosphere and surface water and shallow oceans became mildly oxygenated [97], 
Vladimir F. Niculescu, Stem Cell Biology and Research 2015,

while sub-surface water and deep ocean remain anoxic. (iii) the stage of mildly oxidized deep ocean ( 1.85 to 0.85 GYA) initiated probably by a decrease in the supply of reductants to the deep sea [98]. Interpretations based on proterozoic sulfur [99] dated the transition from the second to the third stage about 1850 MYA, while interpretations based on Proterozoic iron [100] mean the deep ocean remained anoxic until about 800 MYA. Generally, it is admitted that the deep ocean remained anoxic for a long period of time until the rate of oxygen production counterbalanced the geochemistry of the deep ocean reductants [98]. Atmospheric oxygen levels did not change significantly and most of the surface oceans remained mildly oxygenated [97] while sub-surface waters were commonly anoxic [101]. (iv) the stage of increased oxygenated shallow oceans and temporarily anoxic deep ocean (0.85-0.54 GYA) caused by oxygen fluctuations due to ice ages and geologically events (Figure 3 ).

The fact is, $\mathrm{O}_{2}$ became a permanent component of the atmosphere between 2.41 and 2.32 GYA (stage 2). The time period between 2.4 and 2.0 GYA is known as the Great Oxygenation Event (GOE) but the most of the $\mathrm{O}_{2}$ excess was used to transform the geochemical cycle of Fe and of $S$ [97]. During GOE, surface waters must have become progressively more oxygenated and the oxygen concentration of shallow oceans was in equilibrium with the atmospheric oxygen. Stage 3 was rather a static stage without large changes in $\mathrm{O}_{2}$ concentrations. However, some areas of the shallows oceans were oxygen minimum zones (OMZ) and the deep ocean had fluctuating oxygen concentration [97]. On the other hand some of the sub-surface waters were oxygenated [101]. Local conditions controlled redox heterogeneity in subsurface waters. The presence of eukaryotic fossils in basinal shales associated with oxic bottom waters (1400 MYA) is consistent with hypothesis relating early protists to oxygen distribution [101]. At the beginning of stage 4 (800-750 MYA) the great Neoproterozoic Oxygenation Event (NOE) occurred. This was followed by an accumulation of divergent protist morphotypes [102].

The evolutionary history of the eukaryotic stem group (LECA' family) is closely related with the stages 2 and 3 and the environmental niches in Paleo-and Mesoproterozoic populated by the eukaryotic stem group. The oxygenation of surface and sub-surface ocean waters, the associated fluctuations and the co-evolution of nitrogen and carbon cycles in the proterozoic ocean [101] were determinants for LECA's evolution that lasts surely more than 1500 MY. Considering the results from our studies of $E$. invadens, we agree with researchers that presumed LECA's deep history to be in the anoxic water of the Archean near to the Paleoproterozoic boundary [103-105]. Thus, the age of LECA varied widely from $\geq 2500$ MYA to $\geq 1000$ MYA $[103,106,107]$ as the deep eukaryotic supergroups diverged [104]. The unikont-bikont bifurcation, separating Unikonts (uniflagellates) such as Amoebozoa and Opisthokonts (ancestors of animals) from
Bikonts (biflagellates) such as Excavata (Diplomonades and Giardia) is suspected to reside at the base of the eukaryotic tree [108]. To what extent geological records preserve aspects of the deep eukaryotic history is not definitively clarified [105]. Evidence of eukaryotes (protistan microfossils and algae) occurs intermittently in Paleo-and Mezoproterozoic as fossilized formations (encysted structures and cytoskeleton). Morphological diversity was low for the earliest recorded period of protist evolution and many of the protist phyla are not represented in the old fossil records [109]. Archaean rocks (3200-2800 MYA) contain exclusively stem-group protist $[105,110]$ of the LECA family.

There is no doubt that cellular, metabolic and functional evolution of LECA occured in the Paleo- and Mesoproterozoic. Oxygen was a dangerous stressor and in order to survive LECA required efficient detoxification mechanisms. Innovations in metabolic and molecular mechanisms and LGTs from prokaryotes and eukaryotes lead LECA to acquire many developmental innovations and complex genetics [110]. At the beginning LECA had an extremely simple life cycle. It was a metabolically anaerobic organism that proliferated by symmetric division, becoming dormant under unfavorable conditions inside a protective wall. The extent to which the innercyst cell differed from the trophic vegetative stage is unknown. At the time as the eukaryotic super groups diverge LECA had a most complex life-cycle, life cycle stages and distinct vegetative cell types controlled by specific gene sets and subsets, specific for each of its evolutionary phases as well as a multinucleated totipotent innercyst cell with reproductive functions [123].

Environmental oxygen increase and decrease, LECA's response to the nutrient supply [98] and numerous LGTs led to molecular mechanisms for asymmetric cell fate, cell renewing and quiescence by mitotic arrest. These are the fundamental features of modern day eukaryotic stem cells. LECA's life cycle contains finally $\mathrm{SH}, \mathrm{MH} / \mathrm{MO}$ and $\mathrm{MO}$ cell lines corresponding largely to the biogeochemical evolution of the earth $[112,113]$ and the niches where stem-group eukaryotes resided.

Basal molecular mechanisms for stemness and cell differentiation were embedded in LECA'S late life cycle like pearls on a necklace. At the beginning of supergroup divergence LECA's life cycle took more and more the standards of a stable hierarchical stem cell protolineage [111]. Both old and newly acquired mechanisms were transferred from generation to generation and finally to the divergent groups. These protolineage features are conserved in many free-living and pathogen protists living today.

Similarities in the basal mechanisms of stemness found in the distantly related species of Entamoeba, Giardia and mammals suggest that at the time of supergroup divergence, LECA has a variety of genetic adaptations providing molecular mechanisms for life in the strict hypoxic niches from the early Paleoproterozoic (SH cell type) and the low oxygenic and moderate oxygenic niches of the Mesoproterozoic (MH/ 
MO cell types) or in more oxygenic niches of the Meso-/ Neoproterozoic boundary (MO cell type). Researchers such as Douglas A. Melton and Ihor R. Lemischka found in mammalian stem cells 216-283 genes that are active in all types of stem cells studied (ESC, HSC and neural stem cells) and are unique to the particular stem cell type. The authors considered a set of about 200 genes as giving stem cells their special properties for self-renewing, quiescence and differentiation (see McKinney M., "Genes Key to Stem Cells"Stemness' Identified", Sciencexpress 2002;10.1126/science.1072530, 1073823").

Fossils provide little support for any ancient eukaryotic development in the early and mid Proterozoic oceans. Some $1500 \mathrm{MY}$ old protist fossils indicate the molecular capacity for simple multicellularity, exogenous and endogenous signaling features, clusters of cells and bifurcating processes [110]. Such fossils suggest that the cellular and molecular capacity for differentiation evolved early in eukaryotic developement. Some Mesoproterozoic protists fossils have three different cell types, other protists formed cell colonies with an outer layer of cells that protect interior cells from dangerous stressors. Such protists have distinct developmental programs, one for the central cells and another for the peripheral cells. This is similar to the few SRT cells of $E$. invadens embedded in culture sediments in a protective mass of dominant MAT cells (Table 7).

\section{The evolutionary phases of stemness and cell differentiation} The early evolutionary phase and the SH cell type

The strict hypoxic ancestor living in the late Archean -Paleoproterozoic boundary was quite similar to the ISH cells of $E$. invadens. LECA $(\mathrm{SH})$ and its progeny had symmetric cell fate and a two-stage life cycle consisting of a vegetative $\mathrm{SH}$ cell and a resting ITD cyst. Ex-cystment occurred probably at the ratio $1: 1$. ISH cell is the closest relative of LECA (SH) and, in a certain sense a living relic. It conserves mechanisms for identical cell fate, symmetric division and strict hypoxic ITD encystment [111]. A slow decrease of hypoxia stopped LECA (SH) at a checkpoint similarly with the SH checkpoint for ISH/G2 cells. Mitotic arrest of ISH/G2 cells, quiescence and encystment protect LECA (SH) and its DNA from abrupt oxygen damage. LECA's quiescence was at first a mechanism of cell protection against the oxygen stressor.

The middle evolutionary phase and the MH/MO cell type With the beginnings of oxygenation the strict hypoxic molecular mechanisms of the anaerobic LECA were inadequate and became inoperative in the low oxygenated environments. Oxygen and reactive oxygen species (ROS) were toxic and their toxicity meant stress for LECA (SH) that required new mechanisms of detoxifying the oxygen stress. In this evolutionary stage LECA adapted to neutralize ROS by modifying enzymes (catalase, glutathione peroxidase, glutathione transferase) or non-enzymatically, by antioxidands as vitamin $\mathrm{E}$ and $\mathrm{C}$. On the other hand, ROS molecules were used as intermediates in a variety of enzymatic reactions increasing the metabolic rates of replication and proliferation. Prokaryotic LGT probably had an important role in this evolution [114]. Adaptations and mutations gradually led to distinct metabolic pathways with the best probability of surviving in low and middle oxygen niches. At the end of this phase LECA (MH) had an improved anaerobic metabolism best adapted for the vertical oxygen gradients of the Mesoproterozoic ocean. LECA $(\mathrm{MH})$ acquired new mechanisms which allowed it to proliferate in oxygen concentrations between $1 \%$ and $5 \%$. The more $\mathrm{O}_{2}$ that existed in the niche, the faster cell cycling and proliferation proceeded. Meeting SH niches, LECA (MH/ MO) converted transitorily into the previous SH life-style, analogue to the modern day ISH life. ITD encystment occurred from SH cells in strong/strict conditions (anoxic sediments) or in densely populated communities consuming oxygen by detoxification mechanisms.

With such capabilities LECA populations increased explosively, depleting nutrient resources. The quantity of metabolites and mitogens for symmetric division and identical daughter cells became critical. It can be assumed that at a certain time a mother cell has insufficient resources to generate identical daughter cells and division became biased towards an unequal distribution of mitotic suppliers (transcripts). Asymmetric cell fate arises. The mother cell segregates determinants unequally into its progeny [115]. The daughter cell getting sufficient mitogens continues the cell cycle as cycling cell (D1 analogue) and the other (D2 analogue) wait in G0 phase for better times, re-entering the cell cycle as soon as more abundant nutrients appeared. The back and forth swinging between rich and poor nutrient niches led finally to intrinsic mechanisms of asymmetric cell fate and non-identical daughter cells. LECA (MH) encodes the molecular programs for asymmetric cell fate, D2 cell arrest and cell cycle reentry. D2 quiescence remains a mechanism of stem cell protection against stressors. Modifying its cell surface antigenicity-as seen in Giardia [4]- the quiescent cell becomes reversibly differentiated. The modern day cell type best corresponding to LECA $(\mathrm{MH})$ are the tertiary SRT cell of E invadens and Giardia.

\section{The last evolutionary phase}

Is a phase of oxygenic deve-lopment (MO phase). Two major developments chara-cterized this phase. One is the development of a metabolic anaerobe stem cell line proli-ferating exclusively in moderate oxygenic niches without the capacity to live and proliferate in $\mathrm{SH}$ and $\mathrm{MH}$ niches (LECA/MO). The second is the development of an autonomous intrinsic mechanism of endopolyploidization and terminal differentiation linked to this oxygenic cell line. Under this consideration it is questionable if LECA's age ends about $\geq 1000$ MYA $[103,106,107]$ or continues into the Neoproterozoic period (NEO, 800-750 MYA).

Before the divergence of the eukaryotic super-group, LECA proliferates more often in moderate oxygenic environments lacking hypoxic conditions. Under these conditions it decides to 
Vladimir F. Niculescu, Stem Cell Biology and Research 2015,

http://www.hoajonline.com/journals/pdf/2054-717X-2-2.pdf

Table 7. The evolutionary history of stemness and cell differentiation.

\begin{tabular}{|c|c|c|c|c|c|}
\hline $\begin{array}{l}\text { Age } \\
\text { (MYA) }\end{array}$ & Eon & $\begin{array}{l}\text { Main oxygenic } \\
\text { event }\end{array}$ & Oxygenation & Fossil records & $\begin{array}{l}\text { LECA's life } \\
\text { cycle stages }\end{array}$ \\
\hline 3850 & Archean & -- & $\begin{array}{l}\text { Ocean-atmosphere system } \\
\mathrm{O}_{2} \text { free; Oxygen traces by } \\
\text { water photolysis (oases); } \\
\mathrm{H}_{2}, \mathrm{CO}, \mathrm{H}_{2} \mathrm{~S}, \mathrm{Fe} \text { bound } \mathrm{O}_{2}\end{array}$ & -- & $\begin{array}{l}- \\
\text { SH }\end{array}$ \\
\hline 2450 & Paleoproterozoic & GOE & $\begin{array}{l}\text { Reduced substances decreased } \\
\left(\mathrm{H}_{2}, \mathrm{CO}, \mathrm{H}_{2} \mathrm{~S}, \mathrm{Fe}\right) ; \\
\text { Oxygen accumulates in surface } \\
\text { waters; Deep ocean oxygen free }\end{array}$ & $\begin{array}{l}\text { stem-group } \\
\text { Protists }\end{array}$ & $\mathrm{MH}$ \\
\hline 1750 & Mesoproterozoic & $\mathrm{OMZ}$ & $\begin{array}{l}\text { Oxygen fluctuations in the } \\
\text { anoxic deep ocean; } \\
\text { OMZ in shallow oceans; Redox } \\
\text { heterogeneity in sub-surface } \\
\text { waters (static stage) }\end{array}$ & $\begin{array}{l}\text { Cellular differentiation: } \\
3 \text { different cell types; } \\
2 \text { developmental programs } \\
\text { (Knoll et al., 2006, } \\
\text { Butterfield 2004, 2005) }\end{array}$ & $\mathrm{MH} / \mathrm{MO}$ \\
\hline 1000 & Neoproterozoic & -- & $\begin{array}{l}\text { Oxygenated shallow oceans; } \\
\text { Anoxic deep ocean (Ice age) }\end{array}$ & Eukaryotic divergence & $\mathrm{MO}$ \\
\hline 800 & -- & NEO & -- & -- & -- \\
\hline 750 & -- & -- & -- & -- & $\begin{array}{l}\text { stem cell } \\
\text { protolineage }\end{array}$ \\
\hline 540 & Cambrian & -- & -- & Cambrian explosion & -- \\
\hline
\end{tabular}

GOE: Great oxygenation event; OMZ: Oxygen minimum zone; NOE: Neoproterozoic oxygenation event; SH: Strict hypoxic stage; MH: Moderate hypoxic stage; MO: More oxygenic stage

bypass extrinsic signaling and replaced them by a safer terminal differentiation pathway by autonomous mechanisms (ATD encystment). This development brought one of the most important evolutionary steps in the biology of cell differentiation-the autonomous differentiation program. At the end of its proterozoic evolution LECA contains three genes subsets for each of its evolutionary stages $(\mathrm{SH}, \mathrm{MH}, \mathrm{MO})$ and two molecular mechanisms for more hypoxic ITD and more oxygenic ATD encystment. The innercyst cell (metacyst) hatching out from the cyst state established a primary stem cell line that was sensitive towards oxygenic stressors. If this primary cell line encountered a habitat relatively rich in oxygen (MO niche) then it went into a secondary cell line living exclusively in $\mathrm{MO}$ niches by fast cycling and autonomous ATD encystment. When oxygen concentration decreased the secondary cell line converts into a tertiary $\mathrm{MH}$ cell line. If the primary non-continuous cell line encounters less oxygenic environments ( $\mathrm{MO}$ niches) it continues as a tertiary MH cell line capable for ITD encystment.

After the Cambrian explosion, species reside in a greater variety of habitats and many of these species exhibit structural and genetic regressive evolution at the nodes of the eukaryotic evolution as described from fossil kinoms [97]. Similar losses occurred in the protolineage gene subsets with the final result that protist pathogens have today a more intact set of proto- lineage genes while protist commensals have a greater loss [17].

\section{Conclusions and perspectives}

This paper describes in detail the first stem cell system discovered in protists which sheds light on LECA's stemness and details of LECA's complex life cycle. Pathogen protists such as $E$. invadens have conserved to a large extent LECA' stem cell protolineage as it was developed in the Proterozoic. Similar to LECA, E. invadens has a complex life-cycle containing three vegetative stages $(\mathrm{SH}, \mathrm{MH} / \mathrm{MO}$ and $\mathrm{MO})$ and two terminal differentiation patterns namely a more hypoxic ITD (or HTD) induced by extrinsic signaling and a more oxygenic ATD (or OTD) that starts encystment autonomously. It contains all basal mechanisms of stemness and cell differentiation observed in higher eukaryotes. Autonomous terminal differentiation explains "spontaneous" encystment of Entamoeba and Giardia previously described in cultures. The fully conserved ancestral protolineage gene subsets lead to pathogenicity and tissue invasiveness. T stem cells (MAT cells) are the most invasive cells of Entamoebae and the t-SRL line producing MAT cells is the unique immortal stem cell line of the lineage. We consider pathogen protists and especially E. invadens to be a worthwhile organism for studying the basal mechanisms of stemness and hope other protist researchers carry this research field further. 


\section{List of abbreviations}

A cell: Metacystic amoebulae (propagule)

$\mathrm{Aa}(\mathrm{Sm})$ : Culture medium preconditioned by Serratia marcescens containing Aerobacter aerogenes sediments

AaEM: Hypoxic/hypoosmotic encystment medium

AGT: Average generation time

AnSC: Ancient stem cells

ATD: Autonomous terminal differentiation

ASC: Adult stem cells

CE: Cyclic encystment

D1 and D2 cells: Non identical daughter cells

DO: Dissolved oxygen

ESC: Embryonic stem cells

GOE: Great oxygenation event

GYA: Gigayears ago

HSC: Haematopoietic stem cells

iPSC: Induced pluripotent stem cells

INI: Initiation phase of subcultures

ISH: Identical strong hypoxic cells

ITD: Induced terminal differentiation

LECA: Last eukaryotic common ancestor

LGT: Lateral gene transfer

LT: Long term cultures

MA: Mitotic arrested stem cells (quiescent D2)

MAP, MAS, MAT: Primary, secondary and tertiary MA cells

$\mathrm{MH}$ : Moderate hypoxic (niche, life cycle stage)

MO: More oxygenic (niche, life cycle stage)

MYA: Million years ago

NOE: Neoproterozoic oxygenation event

OCB: Oxygen consuming bacteria (OCB niches)

pO2: Oxygen pressure

$\mathrm{P}, \mathrm{S}, \mathrm{T}$ : Primary, secondary and tertiary stem cells

$\mathrm{P} / \mathrm{S}, \mathrm{P} / \mathrm{T}, \mathrm{S} / \mathrm{T}$ : Stem cell conversions

PDP, PDS, PDT: Predecesor cells for P, S, T stem cells

ROS: Reactive oxygen species

RSC: Reserve stem cells

SARC: Stirring and re-centrifugation

$\mathrm{SH}$ : Strict/strong hypoxic (niche, life cycle stage)

SR: Self renewing stem cells (cycling D1 cells)

SRP, SRS, SRT: Primary, secondary and tertiary SR cells

$S R L$ : Self renewing stem cell lines ( $p-S R L, s-S R L, t-S R L)$

TD: Terminal differentiation

\section{Competing interests}

The author declares that he has no competing interests.

\section{Acknowledgement}

The author expresses his gratitude to Dr. Dennis Thomas (native english speaker) for reading of the manuscript and excellent support. The experimental research of this work was supported in part by the Bonn-Konrad-Adenauer-Foundation and Schering AG Berlin. The author is grateful for the friendly support.

Publication history

EIC: Prasad S Koka, Haffkine Institute for Training, Research \&

Testing, India.

Received: 29-Dec-2014 Final Revised: 22-Feb-2015

Accepted: 17-Mar-2015 Published: 24-Mar-2015

\section{References}

1. Niculescu VF. A culture method for study of the cell system in Entamoeba invadens. ICOPA III, Third Intern. Congress of Parasitology, section G3, München. 1974. I Pdf

2. Niculescu VF. The primitive cell system of Entamoeba invadens. ICOPA III, Third Intern. Congress of Parasitology, section A11, München. 1974.
I Pdf

3. Niculescu VF. Growth of Entamoeba invadens in sediments with metabolically repressed bacteria leads to multicellularity and redefinition of the amoebic cell system. Roum Arch Microbiol Immunol. 2013; 72:25-48. I PubMed

4. Niculescu VF. The cell system of Giardia lamblia in the light of the protist stem cell biology. Stem Cell Biol Res. 2014; 1:3. I Article

5. Niculescu VF. Evidence for asymmetric cell fate and hypoxia induced differentiation in the facultative pathogen protist Colpoda cucullus. Microbiol Discov. 2014; 2:3. I Article

6. Niculescu VF. On the Origin of Stemness and Ancient Cell Lineages in Single-Celled Eukaryotes. SOJ Microbiol Infect Dis. 2014; 2: 1-3. | Article

7. Häckel E. Natürliche Schöpfungsgeschichte Berlin. Georg Reimer. 1868.

8. Häckel E. Antropogenie. Leipzig. Wilhelm Engelmann (1 ${ }^{\text {st }}$ edn). 1874.

9. Ramalho-Santos $\mathrm{M}$ and Willenbring $\mathrm{H}$. On the origin of the term "stem cell". Cell Stem Cell. 2007; 1:35-8. I Article I PubMed

10. Knöpfler PS. Who really discovered stem cells? The history you need to known. I Article

11. Becker AJ,Mc CE and Till JE. Cytological demonstration of the clonal nature of spleen colonies derived from transplanted mouse marrow cells. Nature. 1963; 197:452-4. I PubMed

12. Murnaghan I. History of stem cell research . 2014. I Article

13. Funayama $\mathrm{N}$. The stem cell system in demosponges: insights into the origin of somatic stem cells. Dev Growth Differ. 2010; 52:1-14. | Article I PubMed

14. De Sutter D and Buscema M. Isolation of a high pure archaeocyte fraction from the fresh-water sponge Epydatia fluviatilis. Dev. Genes Evol. 1977; 183: 149-153. I Article

15. Rozenfeld F and Rasmont R. Hydroxiurea: an inhibitor of the differentiation of choanocytes in fresh-water sponges and a possible agent for the isolation of embryonic cells. Differentiation 1976; 7:5360.

16. Niculescu VF. Induced synchronous encystment in Entamoeba invadens. Proceedings of the German Society of Parasitology, Tübingen, Germany. 1970. I Article

17. Vicente JB, Tran V, Pinto L, Teixeira M and Singh U. A detoxifying oxygen reductase in the anaerobic protozoan Entamoeba histolytica. Eukaryot Cell. 2012; 11:1112-8. | Article | PubMed Abstract | PubMed Full Text

18. Mukherjee C, Clark CG and Lohia A. Entamoeba shows reversible variation in ploidy under different growth conditions and between life cycle phases. PLoS Neg/ Trop Dis. 2008; 2:e281. | Article I PubMed Abstract I PubMed Full Text

19. Maciera-Coeho Alvaro. Asymmetric Cell Division. In "Progress in Molecular and Subcellular Biology", ed. Maciera-Coeho Alvaro. Springer Verlag, Berlin. 2007.

20. Akbar MA, Chatterjee NS, Sen P, Debnath A, Pal A,Bera T and Das $P$. Genes induced by a high-oxygen environment in Entamoeba histolytica. Mol Biochem Parasitol. 2004; 133:187-96. | Article | PubMed

21. Davis PH, Zhang X, Guo J, Townsend RR and Stanley SL, Jr. Comparative proteomic analysis of two Entamoeba histolytica strains with different virulence phenotypes identifies peroxiredoxin as an important component of amoebic virulence. Mol Microbiol. 2006; 61:1523-32. | Article I PubMed

22. MacFarlane RC and Singh U. Identification of differentially expressed genes in virulent and nonvirulent Entamoeba species: potential implications for amebic pathogenesis. Infect Immun. 2006; 74:340-51. | Article | PubMed Abstract | PubMed Full Text

23. Vicente JB, Ehrenkaufer GM, Saraiva LM, Teixeira M and Singh U. Entamoeba histolytica modulates a complex repertoire of novel genes in response to oxidative and nitrosative stresses: implications for amebic pathogenesis. Cell Microbiol. 2009; 11:51-69. | Article | PubMed Abstract | PubMed Full Text 
Vladimir F. Niculescu, Stem Cell Biology and Research 2015,

24. Di Matteo A, Scandurra FM, Testa F, Forte E, Sarti P, Brunori M and Giuffre $A$. The 02 -scavenging flavodiiron protein in the human parasite Giardia intestinalis. J Biol Chem. 2008; 283:4061-8. | Article | PubMed

25. Brown DM, Upcroft JA and Upcroft P. Free radical detoxification in Giardia duodenalis. Mol Biochem Parasitol. 1995; 72:47-56. | PubMed

26. Bruchhaus I, Richter $S$ and Tannich E. Recombinant expression and biochemical characterization of an NADPH:flavin oxidoreductase from Entamoeba histolytica. Biochem J. 1998; 330:1217-21. | Pdf | PubMed Abstract I PubMed Full Text

27. Schratt G, Weinhold B, Lundberg AS, Schuck S, Berger J, Schwarz H, Weinberg RA, Ruther $U$ and Nordheim $A$. Serum response factor is required for immediate-early gene activation yet is dispensable for proliferation of embryonic stem cells. Mol Cell Biol. 2001; 21:2933-43. | Article | PubMed Abstract | PubMed Full Text

28. Mathieu J, Zhang Z, Nelson A, Lamba DA, Reh TA, Ware C and Ruohola-Baker H. Hypoxia induces re-entry of committed cells into pluripotency. Stem Cells. 2013; 31:1737-48. | Article | PubMed Abstract I PubMed Full Text

29. Shen Q, Goderie SK, Jin L, Karanth N, Sun Y, Abramova N, Vincent P, Pumiglia $K$ and Temple $S$. Endothelial cells stimulate self-renewal and expand neurogenesis of neural stem cells. Science. 2004; 304:1338-40. | Article | PubMed

30. Morrison SJ and Kimble J. Asymmetric and symmetric stem-cell divisions in development and cancer. Nature. 2006; 441:1068-74. | Article | PubMed

31. Shahriyari $L$ and Komarova NL. Symmetric vs. asymmetric stem cell divisions: an adaptation against cancer? PLoS One. 2013; 8:e76195. | Article | PubMed Abstract | PubMed Full Text

32. Zhang YV, Cheong J, Ciapurin N, McDermitt DJ and Tumbar T. Distinct self-renewal and differentiation phases in the niche of infrequently dividing hair follicle stem cells. Cell Stem Cell. 2009; 5:267-78. | Article | PubMed Abstract | PubMed Full Text

33. Marshman E, Booth $C$ and Potten CS. The intestinal epithelial stem cell. Bioessays. 2002; 24:91-8. | Article | PubMed

34. Clayton E, Doupe DP, Klein AM, Winton DJ, Simons BD and Jones PH. A single type of progenitor cell maintains normal epidermis. Nature. 2007; 446:185-9. | Article | PubMed

35. Loeffler M and Roeder I. Tissue stem cells: definition, plasticity, heterogeneity, self-organization and models--a conceptual approach. Cells Tissues Organs. 2002; 171:8-26. | Article | PubMed

36. Rengpien $S$ and Bailey GB. Differentiation of Entamoeba: a new medium and optimal conditions for axenic encystation of $E$. invadens. J Parasitol. 1975; 61:24-30. | PubMed

37. Ruvalcaba Ledezma JC, Latorre Cervantes S, Garcia Romer E, Ramirez Romo S, Mora Galindo J. Encystment and excystation of Entamoeba invadens in vitro as a model to test amebicides against Entamoeba histolytica to the public heath problem Entamoeba dispar. Int J Curr Microbiol and Appl Sci. 2013; 2:263-271. | Pdf

38. Das $S$ and Gillin FD. Chitin synthase in encysting Entamoeba invadens. Biochem J. 1991; 280 ( Pt 3):641-7. | Pdf | PubMed Abstract | PubMed Full Text

39. Turner NA and Eichinger D. Entamoeba invadens: the requirement for galactose ligands during encystment. Exp Parasitol. 2007; 116:467-74. | Article | PubMed Abstract | PubMed Full Text

40. Niculescu VF. The evolutionary history of eukaryotes: how the ancestral proto-lineage conserved in hypoxic eukaryotes led to protist pathogenicity. Microbiol Discov. 2014; 2:4. | Article

41. Muller M, Mentel M, van Hellemond JJ, Henze K, Woehle C, Gould SB, Yu RY, van der Giezen M, Tielens AG and Martin WF. Biochemistry and evolution of anaerobic energy metabolism in eukaryotes. Microbiol Mol Biol Rev. 2012; 76:444-95. | Article | PubMed Abstract | PubMed Full Text

42. Husain A, Sato D, Jeelani G, Soga T and Nozaki T. Dramatic increase in glycerol biosynthesis upon oxidative stress in the anaerobic protozoan parasite Entamoeba histolytica. PLoS Negl Trop Dis. 2012; 6:e1831. |

\section{Article | PubMed Abstract I PubMed Full Text}

43. Weinbach EC and Diamond LS. Entamoeba histolytica. I. Aerobic metabolism. Exp Parasitol. 1974; 35:232-43. | Article | PubMed

44. Mehlotra RK. Antioxidant defense mechanisms in parasitic protozoa. Crit Rev Microbiol. 1996; 22:295-314. | Article | PubMed

45. Montalvo FE, Reeves RE and Warren LG. Aerobic and anaerobic metabolism in Entamoeba histolytica. Exp Parasitol. 1971; 30:249-56. | Article | PubMed

46. Hjort K, Goldberg AV, Tsaousis AD, Hirt RP and Embley TM. Diversity and reductive evolution of mitochondria among microbial eukaryotes. Philos Trans R Soc Lond B Biol Sci. 2010; 365:713-27. | Article | PubMed Abstract | PubMed Full Text

47. Tachezy J and Smid O. Mitosomes in parasitic protists. In: "Hydrogenosomes and mitosomes: mitochondria of anaerobic eukaryotes", pp. 201-230. Ed. J. Tachezy. Springer: Berlin, Heidelberg. 2008.

48. Regoes A, Zourmpanou D, Leon-Avila G, van der Giezen M, Tovar J and Hehl AB. Protein import, replication, and inheritance of a vestigial mitochondrion. J Biol Chem. 2005; 280:30557-63. | Article | PubMed

49. Tsaousis AD, Kunji ER, Goldberg AV, Lucocq JM, Hirt RP and Embley TM. A novel route for ATP acquisition by the remnant mitochondria of Encephalitozoon cuniculi. Nature. 2008; 453:553-6. | Article | PubMed

50. Martin WF and Mentel M. The origin of mitochondria. Nature Education. 2010; 3:58. | Article

51. Mills DB,Ward LM,Jones C,Sweeten B,Forth M,Treusch AH and Canfield DE. Oxygen requirements of the earliest animals. Proc Natl Acad Sci U S A. 2014; 111:4168-72. | Article | PubMed Abstract | PubMed Full Text

52. Sahoo SK, Planavsky NJ, Kendall B, Wang X, Shi X, Scott C, Anbar $A D$, Lyons TW and Jiang G. Ocean oxygenation in the wake of the Marinoan glaciation. Nature. 2012; 489:546-9. | Article | PubMed

53. Campbell, Neil A, Reece and Jane B. In “Biology" (7th ed). 526.

54. Peterson KJ and Butterfield NJ. Origin of the Eumetazoa: testing ecological predictions of molecular clocks against the Proterozoic fossil record. Proc Natl Acad Sci U S A. 2005; 102:9547-52. | Article | PubMed Abstract I PubMed Full Text

55. Erwin DH, Laflamme M, Tweedt SM, Sperling EA, Pisani D and Peterson $\mathrm{KJ}$. The Cambrian conundrum: early divergence and later ecological success in the early history of animals. Science. 2011; 334:1091-7. Article | PubMed

56. Sperling EA, Pisani D and Peterson KJ. Poriferan paraphyly and its implications for Precambrian palaeobiology. Geol Soc Lond Spec Publ. 2007; 286:355-368. | Article

57. Nosenko T, Schreiber F, Adamska M, Adamski M, Eitel M, Hammel J, Maldonado M, Muller WE, Nickel M, Schierwater B, Vacelet J, Wiens $M$ and Worheide $G$. Deep metazoan phylogeny: when different genes tell different stories. Mol Phylogenet Evol. 2013; 67:223-33. | Article | PubMed

58. Philippe H, Brinkmann H, Lavrov DV, Littlewood DT, Manuel M, Worheide $G$ and Baurain D. Resolving difficult phylogenetic questions: why more sequences are not enough. PLOS Biol. 2011; 9:e1000602. | Article I PubMed Abstract I PubMed Full Text

59. Runnegar B. Oxygen requirements, biology and phylogenetic significance of the late Precambrian worm Dickinsonia, and the evolution of the burrowing habit. Alcheringa Australasian J Palaeontol. 1982; 6:223-239. | Article

60. Sperling EA, Halverson GP, Knoll AH, Macdonald FA and Johnston DT. A basin redox transect at the dawn of animal life. Earth Planet Sci Lett. 2013; 372:143-155. | Article

61. Maldonado M. Choanoflagellates, choanocytes, and animal multicellularity. Invertebr Biology. 2004; 123:1-22. | Pdf

62. Ruthmann $A$. The fine structure of RNA-storing archaeocytes from gemules of fresh-water sponges. Quart J Micr Sci. 1965; 106: 99-114. | Article

63. Poole RK. Mitochondria of Tetrahymena pyriformis: enumeration and sizing of isolated organelles using a coulter counter and pulse-height 
analysis. J Cell Sci. 1983; 61:437-451. | Pdf

64. Steinman RA. Cell cycle regulators and hematopoiesis. Oncogene. 2002; 21:3403-3413.

65. Morrison SJ and Weissman IL. The long-term repopulating subset of hematopoietic stem cells is deterministic and isolatable by phenotype. Immunity. 1994; 1:661-73. | Article | PubMed

66. Ito $K$ and Suda T. Metabolic requirements for the maintenance of selfrenewing stem cells. Nat Rev Mol Cell Biol. 2014; 15:243-56. | Article | PubMed Abstract | PubMed Full Text

67. Suda T, Takubo $K$ and Semenza GL. Metabolic regulation of hematopoietic stem cells in the hypoxic niche. Cell Stem Cell. 2011; 9:298-310. | Article | PubMed

68. Mohyeldin A, Garzon-Muvdi T and Quinones-Hinojosa A. Oxygen in stem cell biology: a critical component of the stem cell niche. Cell Stem Cell. 2010; 7:150-61. | Article | PubMed

69. Hsu P and Qu CK. Metabolic plasticity and hematopoietic stem cell biology. Curr Opin Hematol. 2013; 20:289-94. | Article | PubMed Abstract | PubMed Full Text

70. Folmes CD, Dzeja PP, Nelson TJ and Terzic A. Metabolic plasticity in stem cell homeostasis and differentiation. Cell Stem Cell. 2012; 11:596-606. | Article | PubMed Abstract | PubMed Full Text

71. Zhang J, Nuebel E, Daley GQ, Koehler CM and Teitell MA. Metabolic regulation in pluripotent stem cells during reprogramming and selfrenewal. Cell Stem Cell. 2012; 11:589-95. | Article | PubMed Abstract | PubMed Full Text

72. Ito K, Hirao A, Arai F, Matsuoka S, Takubo K, Hamaguchi I, Nomiyama K, Hosokawa K, Sakurada K, Nakagata N, Ikeda Y, Mak TW and Suda T. Regulation of oxidative stress by ATM is required for self-renewal of haematopoietic stem cells. Nature. 2004; 431:997-1002. | Article | PubMed

73. Owusu-Ansah E and Banerjee U. Reactive oxygen species prime Drosophila haematopoietic progenitors for differentiation. Nature. 2009; 461:537-41. | Article | PubMed

74. Wilson A, Laurenti E, Oser G, van der Wath RC, Blanco-Bose W, Jaworski $M$, Offner S, Dunant CF, Eshkind L, Bockamp E, Lio P, Macdonald HR and Trumpp A. Hematopoietic stem cells reversibly switch from dormancy to self-renewal during homeostasis and repair. Cell. 2008; 135:111829. | Article | PubMed

75. Takizawa H, Regoes RR, Boddupalli CS, Bonhoeffer S and Manz MG. Dynamic variation in cycling of hematopoietic stem cells in steady state and inflammation. J Exp Med. 2011; 208:273-84. | Article | PubMed Abstract | PubMed Full Text

76. Simsek T, Kocabas F, Zheng J, Deberardinis RJ, Mahmoud Al, Olson EN, Schneider JW, Zhang CC and Sadek HA. The distinct metabolic profile of hematopoietic stem cells reflects their location in a hypoxic niche. Cell Stem Cell. 2010; 7:380-90. | Article | PubMed Abstract | PubMed Full Text

77. Wilson A and Trumpp A. Bone-marrow haematopoietic-stem-cell niches. Nat Rev Immunol. 2006; 6:93-106. | Article | PubMed

78. Folmes CD, Nelson TJ, Martinez-Fernandez A, Arrell DK, Lindor JZ, Dzeja PP, Ikeda Y, Perez-Terzic C and Terzic A. Somatic oxidative bioenergetics transitions into pluripotency-dependent glycolysis to facilitate nuclear reprogramming. Cell Metab. 2011; 14:264-71. | Article | PubMed Abstract | PubMed Full Text

79. Liu Y, Elf SE, Miyata Y, Sashida G, Huang G, Di Giandomenico S, Lee JM, Deblasio A, Menendez S, Antipin J, Reva B, Koff A and Nimer SD. p53 regulates hematopoietic stem cell quiescence. Cell Stem Cell. 2009; 4:37-48. | Article | PubMed Abstract | PubMed Full Text

80. Attar EC and Scadden DT. Regulation of hematopoietic stem cell growth. Leukemia. 2004; 18:1760-8. | Article | PubMed

81. Passegue E, Wagers AJ, Giuriato S, Anderson WC and Weissman IL. Global analysis of proliferation and cell cycle gene expression in the regulation of hematopoietic stem and progenitor cell fates. J Exp Med. 2005; 202:1599-611. | Article | PubMed Abstract | PubMed Full Text

82. Forsberg EC, Prohaska SS, Katzman S, Heffner GC, Stuart JM and Weissman IL. Differential expression of novel potential regulators in hematopoietic stem cells. PLoS Genet. 2005; 1:e28. | Article | PubMed Abstract | PubMed Full Text

83. Venezia TA, Merchant AA, Ramos CA, Whitehouse NL,Young AS,Shaw CA and Goodell MA. Molecular signatures of proliferation and quiescence in hematopoietic stem cells. PLoS Biol. 2004; 2:e301. | Article | PubMed Abstract | PubMed Full Text

84. Ito K, Hirao A, Arai F, Takubo K, Matsuoka S, Miyamoto K, Ohmura M, Naka K, Hosokawa K, Ikeda $Y$ and Suda T. Reactive oxygen species act through p38 MAPK to limit the lifespan of hematopoietic stem cells. Nat Med. 2006; 12:446-51. | Article | PubMed

85. Sablina AA, Budanov AV, llyinskaya GV, Agapova LS, Kravchenko JE and Chumakov PM. The antioxidant function of the $\mathrm{p} 53$ tumor suppressor. Nat Med. 2005; 11:1306-13. | Article | PubMed Abstract | PubMed Full Text

86. Eliasson $P$ and Jonsson JI. The hematopoietic stem cell niche: low in oxygen but a nice place to be. J Cell Physiol. 2010; 222:17-22. | Article I PubMed

87. Panchision DM. The role of oxygen in regulating neural stem cells in development and disease. J Cell Physiol. 2009; 220:562-8. | Article | PubMed

88. Oliver JA, Maarouf O, Cheema FH, Martens TP and Al-Awqati Q. The renal papilla is a niche for adult kidney stem cells. J Clin Invest. 2004; 114:795-804. | Article | PubMed Abstract | PubMed Full Text

89. Panchision $\mathrm{DM}$. The role of oxygen in regulating neural stem cells in development and disease. J Cell Physiol. 2009; 220:562-8. | Article | PubMed

90. Chow DC, Wenning LA, Miller WM and Papoutsakis ET. Modeling pO(2) distributions in the bone marrow hematopoietic compartment. II. Modified Kroghian models. Biophys J. 2001; 81:685-96. | Article | PubMed Abstract | PubMed Full Text

91. Ezashi T,Das $\mathbf{P}$ and Roberts RM. Low $\mathbf{O} 2$ tensions and the prevention of differentiation of hES cells. Proc Natl Acad Sci U S A. 2005; 102:4783-8. | Article | PubMed Abstract | PubMed Full Text

92. Lo Celso C, Fleming HE, Wu JW, Zhao CX, Miake-Lye S, Fujisaki J, Cote D, Rowe DW, Lin CP and Scadden DT. Live-animal tracking of individual haematopoietic stem/progenitor cells in their niche. Nature. 2009; 457:92-6. | Article | PubMed Abstract | PubMed Full Text

93. Xie Y,Yin T, Wiegraebe W, He XC, Miller D, Stark D, Perko K, Alexander R, Schwartz J, Grindley JC, Park J, Haug JS, Wunderlich JP, Li H, Zhang S, Johnson T, Feldman RA and Li L. Detection of functional haematopoietic stem cell niche using real-time imaging. Nature. 2009; 457:97-101. | Article | PubMed

94. Samuelson J. What Entamoeba histolytica and Giardia lamblia tell us about the evolution of eukaryotic diversity. J. Biosci. 2002; 27:559565. | Pdf

95. Hasegawa M, Hashimoto T, Adachi J, Iwabe $\mathrm{N}$ and Miyata T. Early branchings in the evolution of eukaryotes: ancient divergence of entamoeba that lacks mitochondria revealed by protein sequence data. J Mol Evol. 1993; 36:380-8. | Article | PubMed

96. Manning $G$, Reiner DS, Lauwaet T, Dacre M, Smith A, Zhai Y, Svard S and Gillin FD. The minimal kinome of Giardia lamblia illuminates early kinase evolution and unique parasite biology. Genome Biol. 2011; 12:R66. | Article | PubMed Abstract | PubMed Full Text

97. Holland HD. The oxygenation of the atmosphere and oceans. Philos Trans R Soc Lond B Biol Sci. 2006; 361:903-15. | Article I PubMed Abstract | PubMed Full Text

98. Fenel K, Follows $\mathrm{M}$ and Falkowski PG. The co-evolution of the nitrogen, carbon and oxygen cycles in the proterozoic ocean. Am J Sci. 2005; 305:526-545. | Pdf

99. Kasting JF. Earth history: the chemical evolution of the atmosphere and oceans. Science. 1984; 226:332-3. | Article | PubMed

100. Canfield DE. A new model for Proterozoic ocean chemistry. Nature. 1998; 396:450-454. | Pdf

101. Sperling EA, Rooney AD, Hays L, Sergeev VN, Vorob'eva NG, Sergeeva ND, Selby D, Johnston DT and Knoll AH. Redox heterogeneity of subsurface waters in the Mesoproterozoic ocean. Geobiology. 2014; 
Vladimir F. Niculescu, Stem Cell Biology and Research 2015,

http://www.hoajonline.com/journals/pdf/2054-717X-2-2.pdf

doi: $10.7243 / 2054-717 \mathrm{X}-2-2$

12:373-86. | Article | PubMed

102. Och LM. Biogeochemical cycling through the NeoproterozoicCambrian transition in China: an integrated study of redox-sensitive elements. Thesis, University College London (UCL). 2011.

103. Parfrey LW, Lahr DJ, Knoll AH and Katz LA. Estimating the timing of early eukaryotic diversification with multigene molecular clocks. Proc Natl Acad Sci U S A. 2011; 108:13624-9. | Article | PubMed Abstract | PubMed Full Text

104. Keeling PJ, Burger G, Durnford DG, Lang BF, Lee RW, Pearlman RE, Roger AJ and Gray MW. The tree of eukaryotes. Trends Ecol Evol. 2005; 20:670-6. | Article | PubMed

105. Knoll AH. Paleobiological perspectives on early eukaryotic evolution. Cold Spring Harb Perspect Biol. 2014; 6: a016121. I Article I PubMed

106. Katz LA, Grant JR, Parfrey LW and Burleigh JG. Turning the crown upside down: gene tree parsimony roots the eukaryotic tree of life. Syst Biol. 2012; 61:653-60. | Article I PubMed Abstract | PubMed Full $\underline{\text { Text }}$

107. Eme L, Sharpe SC, Brown MW and Roger AJ. On the age of eukaryotes: evaluating evidence from fossils and molecular clocks. Cold Spring Harb Perspect Biol. 2014; 6. I Article I PubMed

108. Minge MA, Silberman JD, Orr RJ, Cavalier-Smith T, Shalchian-Tabrizi K, Burki F, Skjaeveland A and Jakobsen KS. Evolutionary position of breviate amoebae and the primary eukaryote divergence. Proc Biol Sci. 2009; 276:597-604.| Article | PubMed Abstract | PubMed Ful Text

109. Knoll AH. Proterozoic and early Cambrian protists: evidence for accelerating evolutionary tempo. Proc Natl Acad Sci U S A. 1994; 91:6743-50. | Pdf | PubMed Abstract | PubMed Full Text

110. Knoll $A H$, Javaux EJ, Hewitt $D$ and Cohen P. Eukaryotic organisms in Proterozoic oceans. Philos Trans R Soc Lond B Biol Sci. 2006; 361:102338. | Article | PubMed Abstract | PubMed Full Text

111. Niculescu VF. The evolutionary history of eukaryotes: how the ancestral proto-lineage conserved in hypoxic eukaryotes led to protist pathogenicity. Microbiology Discovery. 2014; 2:4. | Article

112. Walker JCG, Klein C, Schidlowski M, Schopf JW, Stevenson DJ and Walter MR. Environmental evolution of the Archean-Early Proterozoic earth. In "Earth's earliest biosphere: Its origin and evolution" p.260-290, ed. Schopf JW. Princeton, Princeton University Press. 1983.

113. Kasting JF, Holland HD and Kump LR. Atmospheric evolution: the rise of oxygen. In "The Proterozoic Biosphere" pp. $159-163$, eds. Schopf JW and Klein C. Cambridge University Press, New York. 1992.

114. Boucher Y, Douady CJ, Papke RT, Walsh DA, Boudreau ME, Nesbo CL, Case RJ and Doolittle WF. Lateral gene transfer and the origins of prokaryotic groups. Annu Rev Genet. 2003; 37:283-328. | Article | PubMed

115. Guo M, Jan LY and Jan YN. Control of daughter cell fates during asymmetric division: interaction of Numb and Notch. Neuron. 1996; 17:27-41. | Article | PubMed

116. Andersson JO, Sjogren AM, Davis LA, Embley TM and Roger AJ. Phylogenetic analyses of diplomonad genes reveal frequent lateral gene transfers affecting eukaryotes. Curr Biol. 2003; 13:94-104. | Article I PubMed

117. Andersson JO,Hirt RP,Foster PG and Roger AJ. Evolution of four gene families with patchy phylogenetic distributions: influx of genes into protist genomes. BMC Evol Biol. 2006; 6:27. | Article | PubMed Abstract | PubMed Full Text

118. Mayol JM, Adame-Navarrete $Y$, Alarma-Estrany P, Molina-Roldan E, Huete-Toral F and Fernandez-Represa JA. Luminal oxidants selectively modulate electrogenic ion transport in rat colon. World J Gastroenterol. 2006; 12:5523-7. | PubMed Abstract I PubMed Full Text

119. Carreau A, El Hafny-Rahbi B, Matejuk A, Grillon C and Kieda C. Why is the partial oxygen pressure of human tissues a crucial parameter? Small molecules and hypoxia. J Cell Mol Med. 2011; 15:1239-53. | Article I PubMed

120. Butterfield NJ. A vaucheriacean alga from the middle Neoproterozoic of Spitsbergen: implications for the evolution of Proterozoic eukaryotes and the Cambrian explosion. Paleobiology. 2004; 30;
231-252. | Article

121. Butterfield NJ. Probable Proterozoic fungi. Paleobiology. 2005; 31:165-182. | Article

122. Shiflett AM and Johnson PJ. Mitochondrion-related organelles in eukaryotic protists. Annu Rev Microbiol. 2010; 64:409-29. | Article | PubMed Abstract | PubMed Full Text

123. Niculescu VF. Endopolyploidy and terminal differentiation in the ancient stem cell lineage of Entamoeba invadens. 2015.

124. Dutta GP. Metacystic divisions in the life-cycle of Entamoeba histolytica Schaudinn, 1903, in man. 1960. I Pdf

125. Topic on Zoology. Entamoeba histolytica. Competition Science Vision. 2006; 9:369.

\section{Citation:}

Niculescu VF. The stem cell biology of the protist pathogen Entamoeba invadens in the context of eukaryotic stem cell evolution. Stem Cell Biol Res. 2015; 2:2. http://dx.doi.org/10.7243/2054-717X-2-2 